\title{
DIMENSIONS IN POST-INDUSTRIAL LAND TRANSFORMATION IN PLANNING AND DESIGN: A PORTUGESE CASE STUDY CONCERNING PUBLIC PERCEPTION ${ }^{1}$
}

\author{
L. Loures ${ }^{2}$, J. B. Burley ${ }^{3}$, T. Panagopoulos ${ }^{4}$, and Jing Zhou ${ }^{5}$
}

\begin{abstract}
Planners and designers are often interested in the criteria, values, and principles employed to create an intervention. In our study, we were interested in respondents' guiding beliefs and principles associated with post-industrial land reclamation. Experts have proposed heuristically, dimensions and sets of guiding planning and design beliefs associated with post-industrial reclamation. We were interested in determining whether these expertly derived dimensions matched the thinking of the population at large. To conduct our study, we started with examining six noted, post-industrial projects to derive a set (list) of design criteria from professionals who worked upon these projects. We then engaged European planning and design professionals and citizens from southern Portugal to examine the mathematical/statistical ordination of these principles. The study revealed that the principles as expressed by the public are structured and organized differently compared to what experts have proposed. The public's perceptions, expectations, and values are dispersed across numerous independent dimensions (seven to twelve or even larger) and are much more complex than the simplistic interpretations presented in the literature by experts. Our study suggests that public expectations concerning post-industrial reclamation are broadly multi-dimensional and arrayed with many variables; it is not simple and not easy to intellectually grasp. The results reflect the complicated set of citizen expectations associated with reclamation projects. To satisfy this set of expectations may not be an easy task. In the successful planning, design, and construction of post-industrial sites, these values/principles/beliefs can form the beginning of a thoughtful program of criteria to begin the planning/design process.
\end{abstract}

Additional Key Words: environmental design, landscape architecture, environmental psychology, urban design, multivariate analysis, social science, urban ecology, urban anthropology

\footnotetext{
1. Paper submitted for consideration for pubublication in JASMR and was not presented at our conferences that were held in the past, R.I. Barnhisel (Ed.) Published by ASRS, 1305 Weathervane, Champaign, IL 61821

${ }^{2}$ Dr. Luis Loures is Professor, and Vice-Rector of the Polytechnic Institute of Portalegre, Portugal;

${ }^{3}$ Dr. Jon Bryan Burley is in the Landscape Architecture Program at the School of Planning, Design, and Construction, College of Social Science and College of Agriculture and Natural Resources, Michigan State University, E. Lansing, MI, 48824, USA

${ }^{4}$ Dr. Thomas Panagopoulos is Professor with the Faculty of Science and Technology, University of Algarve, Portugal,

5 Jing Zhou is a PhD student in Environmental Design at Planning, Design, and Construction at Michigan State University, E. Lansing, MI, 48824, USA.
} 


\section{$\underline{\text { Introduction }}$}

It has been accepted by many that the landscape is continuously changing (Jinyan, 2003; PintoCorreia et al., 2001) as a result of complex and interacting natural processes coupled with planned and unplanned actions by man. A relatively recent paper by Burley, Fernandes, and Cabeleira (2006) illustrate this change over time in Southern Portugal, as the landscape use and patterns were reinvented by humans several times in the last 6,000 years. This inherent characteristic of landscape may be noted on the Germanic definition of word landschaft that "connotes landscape as a changing system of social and ecological interrelations" (Czerniak, 2006), relating people and place (Spirn, 1998). However, this ongoing "transformation of landscapes worldwide (...) has raised global concerns" (Musacchio et al., 2005), as is the need to rethink landscape and protect open spaces. This is particularly true for previously developed areas given the fact that the redevelopment of former underused landscapes, as opposed to consuming new formerly less touched environments, is considered a proficient approach to achieve sustainable urban planning (De Sousa, 2003; Panagopoulos and Loures, 2007; Portney, 2003).

Reclaiming land is an example of this landscape change. The definition and understanding of the term "reclamation" has expanded from primarily improving dry lands (such as in the American West) and recovering land from the sea (as in the Netherlands), to making highly disturbed surfacemined lands useful and productive after mining, to the present inclusion of finding acceptable uses for environments that were once industrial (Burley and Machemer, 2016; Burley, 2001). Reclamation even included saving and protecting unique environments from the ravages of past reclamation plans (Burley, 1989). As landscape cover and land uses evolve and change, the processes associated with this change is socially related and not necessarily independent from land use to land use. These concepts form the underlying planning and design principles in the surface mine and reclamation literature (Burley, 2001). These formative and fundamental ideas have emerged in urban planning and open space design. In fact "it has long been realized that urban planning and open space preservation are part of the same process" (Hollis and Fulton, 2002), "and that the most effective way to protect open space is by effectively containing and managing urban growth" (Alterman, 1997; Tyman, 2008). This is also true in regard to reclamation planning and design, it is one continuous process of changing land uses and plans. In this regard, land transformation policies, strategies and methodologies have been considered a important tools for urban containment, fostering urban redevelopment, revitalization, and managing land (Willem, 2009; Urban Land Institute, 2004; Adams and Watkins, 2002; Burley, 2001). The evolution of the American Society for Reclamation Sciences (ASRS), reflects this progression growing from an 
Eastern American coal mining consortium to a broad, global surface mining research and reclamation organization, to investigations concerning many kinds of landscape disturbance, which now includes post-industrial reclamation. Therefore, industrial land is not abandoned, just like surface-mined land is not abandoned, but rather post-industrial land is transformed into something again useful, just as mined land is transformed into something useful (Figs. 1 and 2). By reclaiming these environments, the activity reduces the pressures to transform green fields and wilderness (Burley, Loures, and Feng, 2012). Many planners, designers, and engineers are adept at redeveloping sites, fully utilizing in-fill sites (often left over properties with development challenges), and optimizing the use of the land.

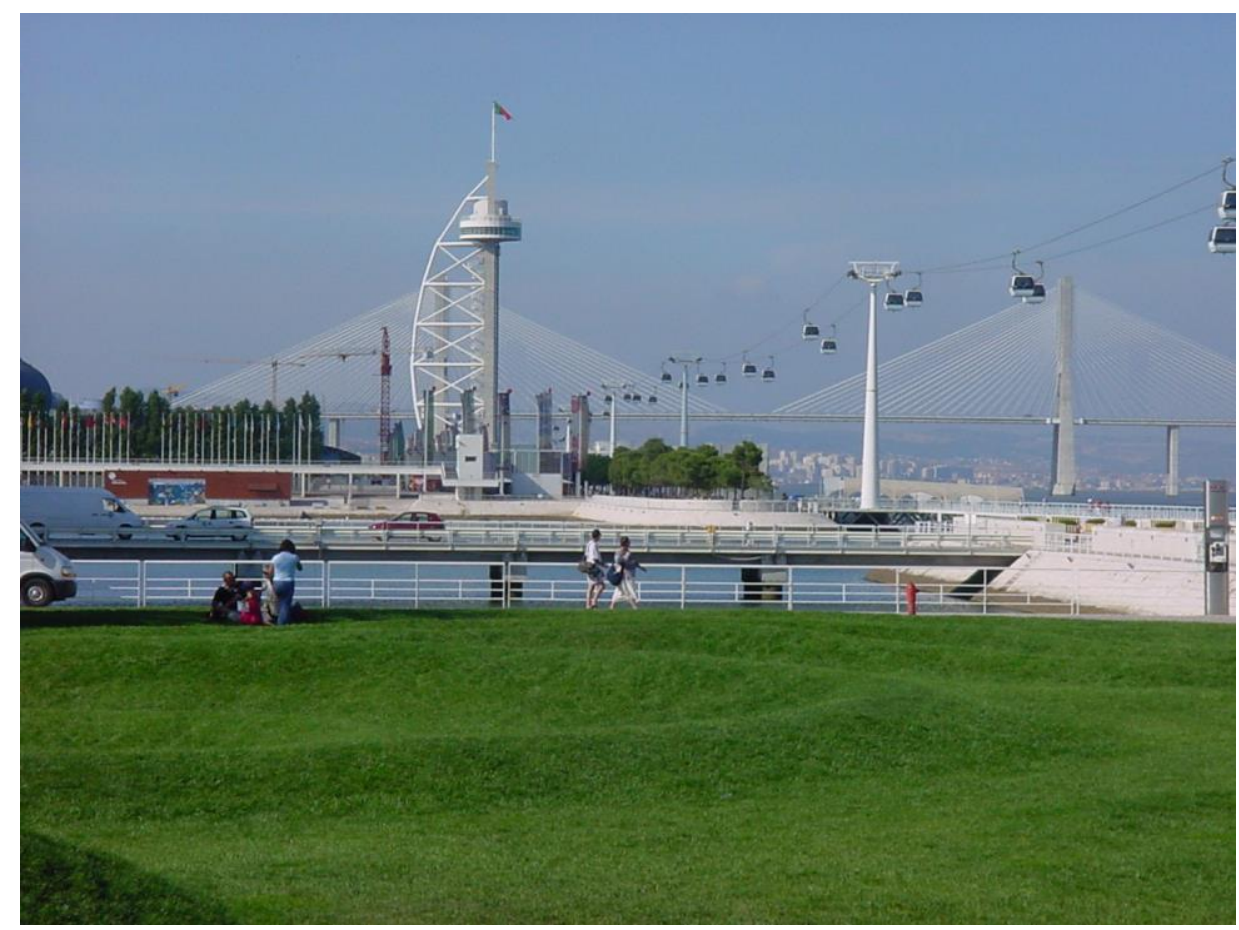

Figure 1. This image was taken in the Parque das Nações (Park of the Nations), Lisbon, Portugal, looking north towards the Vasco da Gama Bridge (1998) and the 145m tall Vasco da Gama Tower (1998). The bridge spans a tidal portion of the Tagus River and is the longest bridge $(12.3 \mathrm{~km})$ in the European Union. The site was at one time a large oil refinery, but became a post-industrial reclamation site hosting the 1998 Lisbon World Exposition. Telecabine (Cable Car/Gondola) traverses the site (built in 1998). The park contains a large shopping mall (Vasco da Gama Mall), an aquarium (Lisbon Oceanarium), the Altice Arena (Atlantic Arena), a large marina, and the Gare do Oriente (a train, subway, and bus station designed by Santiago Calatrava) (Editorial Blau, Lda, 1998). The site is just south of the Reserva Natural do Estuário do Tejo (Tagus Estuary Natural Reserve), the largest estuary in Western Europe, (Copyright @ 2003 Jon Bryan Burley all rights reserved, used by permission). 


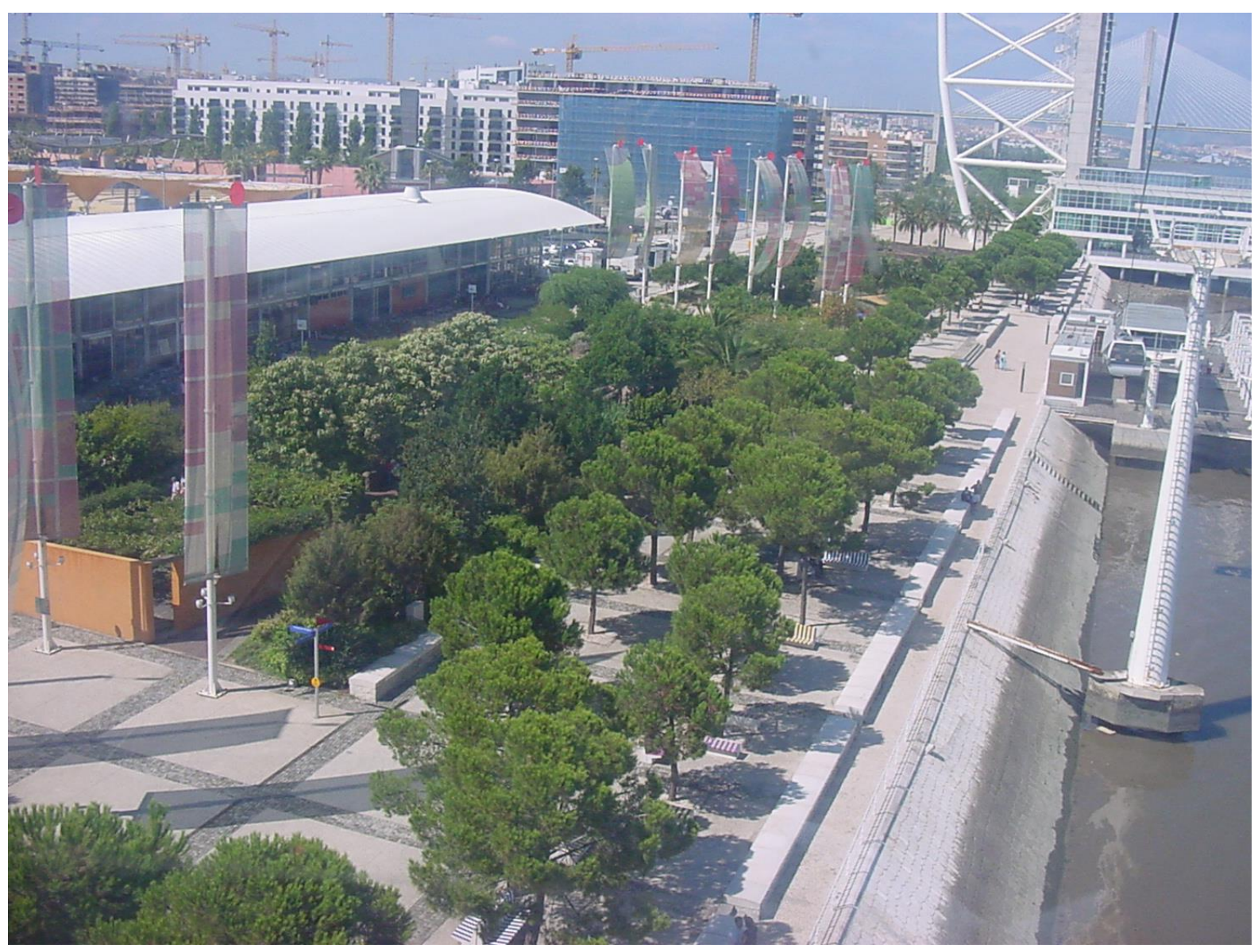

Figure 2. A view of the Parque das Nações (Park of the Nations), taken from the Telecabine (Cable Car/Gondola) overlooking the park-like setting. There are many gardens and water features in the park, (Copyright (C) 2003 Jon Bryan Burley all rights reserved, used by permission).

The contributions and the principles associated with post-industrial land transformation have not been as intensively studied as surface mine reclamation. The knowledge base may be less studied and reported. Reclaiming industrial land may be considered a proficient approach to combat urban sprawl, increasingly viewed as significant and growing problems that entail a wide range of social, economic, and environmental costs (Bengston et al., 2004; Johnson, 2001; Brueckner, 2000). Yet, thoughtful industrial land integration and reclamation is not necessarily new. The late Sir Geoffrey Jellicoe (1900-1996) described two projects, the Oldbury-on-Severn Nuclear Power Station in the 1960s and the Rutherford High Energy Laboratory, Harwell excavated chalk reclamation project (1962), both in the United Kingdom (Jellicoe, 1996). On the Oldbury-on-Severn Nuclear Power Station, the issue was integrating the industrial environment with the surrounding agricultural land. For the Rutherford High Engery Laboratory, the issue was how to sculpt the excavated chalk into a meaningful and environmentally responsible landform. While these projects are on relatively small sites, post-industrial reclamation can occur over large 
expanses of land, just as coal mining in Wyoming covers large expanses of the landscape. In westcentral Germany (the Ruhr region), a landscape mined for its underground coal resources which was transformed after the coal was gone, land subsidence had ceased, and the industry dependent upon the coal had departed. This is a large mining and post-industrial reclamation project (Fig. 3)

(Gilhaus et al., 2011; Hermann and Hermann, 2008; and Peters, 1999).

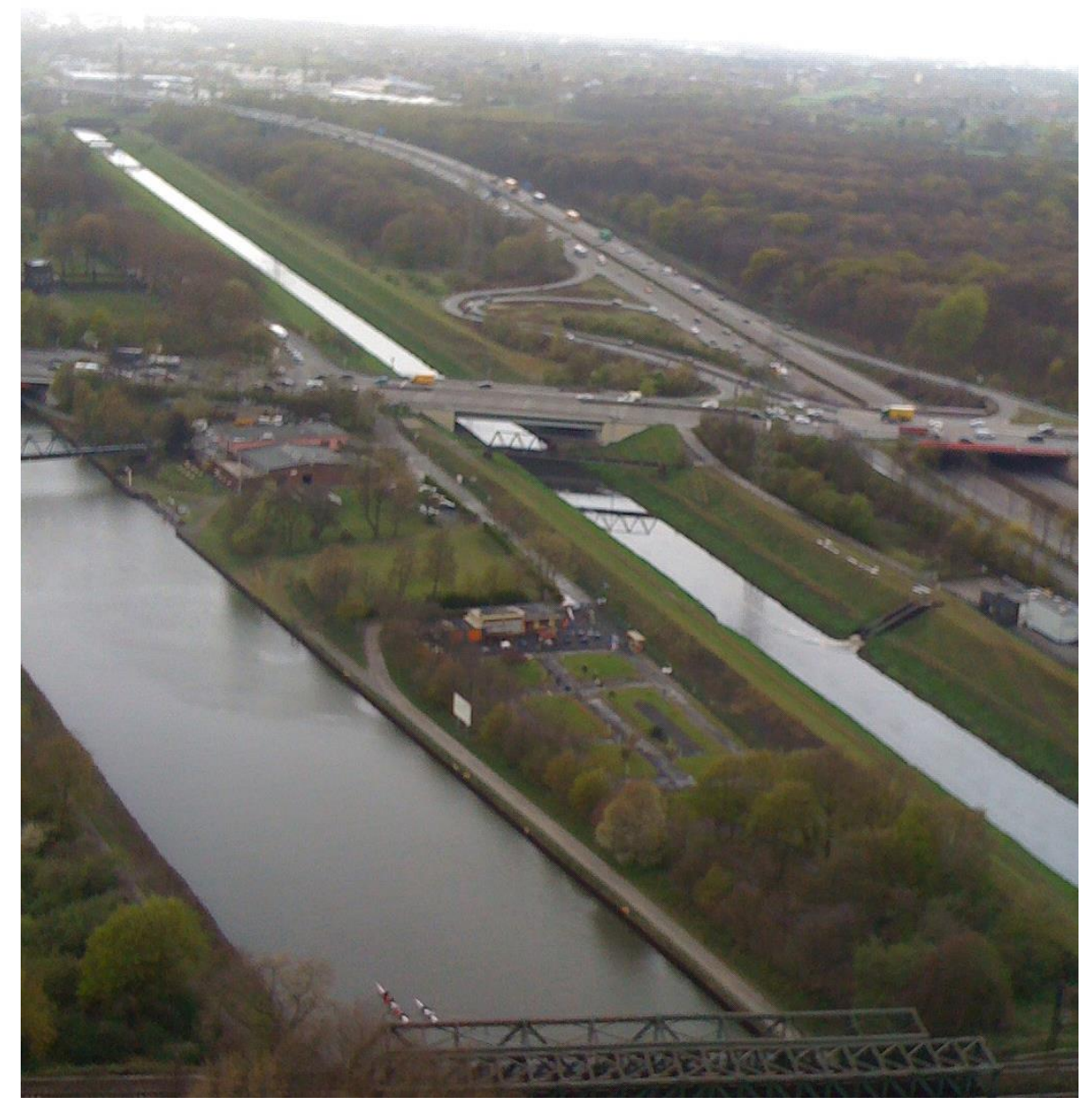

Figure 3. This is a picture of the Ruhr industrial area in Germany as viewed from the top of an old gasification storage tank (the Gasometer) Oberhausen, Germany looking west, in the general direction toward the famous Duisburg-Nord Landschaftspark (which would be just left of the image) and the Rhine River beyond the horizon. The landscape as far as the eye can see in this image is an extensively reclaimed post-industrial site. In the foreground is the Rhein-Herne Kanal, the smaller chanalized Emscher River, and the Autobahn 42. (Copyright (C) 2012 Jon Bryan Burley all rights reserved, used by permission). Peters (1999) has a reverse view of the storage tank with some of the same bridges and waterbodies, but before the Autobahn, (page 117). The Gasometer is now an exhibition center and observation tower. Much of the Emscher, especially near Dortmund, has been recently reconfigured and naturalized. 
The relevance and popularity of these land transformation tools/approaches is increasingly recognized and as referred by Reed (2005) "nearly every significant new landscape designed in recent years occupies a site that has been reinvented and reclaimed from obsolescence or degradation, as cities in post-industrial era remake and redefine their outdoor spaces." In places like China, India, southwestern Asia, northwestern Africa, and Central America where civilized land occupation has been prevalent for many millennium, this is especially true. Still, questions such as: What will we do with these landscapes? Which functions might these areas acquire in the future? What makes these spaces underutilized? What obstacles keep these landscapes from being transformed? Who is responsible for transforming them? Who is best qualified to do it? Is this process a single profession endeavor? Among others questions, the issues remain to be answered, although some of the answers can be found or suggested in Burley (2001). For this reason, new methodologies and frameworks are explored. In a period when "(...) that seemingly old-fashioned term landscape has curiously come back to vogue" (Corner in Waldheim, 2006), it is urgent to reinvent the way in which these post-industrial landscapes are transformed, considering not only environmental issues but also historic and cultural values, economic opportunities, and social needs.

The origin of this growing concern may be traced from a period when industry, the source of every evil and every good, became one of the main protagonists in the transformation of the city (Rossi, 1982). However, the consequences of the globalization of industry, relocation and restructuration of several industrial sectors over the past decades had a profound effect on quite a lot of industrial areas all over the world, producing a vast array of obsolete industrial facilities with various impacts generated from them (Antrop, 2000). For this reason numerous countries, all over the world, have undergone countless post-industrial land transformation projects (generally known as rehabilitation, revitalization, reclamation, and/or redevelopment programs), in order to mitigate the negative effects arisen from these changes. In this scenario it is increasingly recognized that managing urban growth, transforming underused landscapes, and protecting open space constitute relevant efforts to achieve sustainable urban planning. Though, whether or not, these efforts will be sufficient to make development environmentally, economically, and socially sustainable remains to be seen.

It is no longer a new notion that the formal products of the modern period have become obsolete, forcing this generation to decide on the disposition of the last generation's industrial environment. The international industrial climate, which Pirelli (1987) has termed as the third industrial revolution, has rendered obsolete several industrial structures, technologies, and 
processes of the first half of the twentieth century. Demolition and abandonment were and continue to be "fairly common approaches to deal with facilities that were designated as 'surplus' no longer serving their original production functions" (Rea, 1991). In Portugal, as well as in several other countries, it is gradually more common to find older buildings, characteristic of the industrial society, simply abandoned, surviving alongside with recent development areas.

Nevertheless, the creation of new and more severe environmental legislation, and the public pressure related with the need to protect the environment, have increased the necessity to redevelop post-industrial sites (Loures et al., 2006), considered by many as unrealized resources for initiating urban regeneration and ecological restoration (Brebbia et al., 2002). Often in advantageous locations near city centers, along waterfronts, supported by existing infrastructure, and adjacent to residential communities, these landscapes are environmentally impaired resources that need to be returned to productive uses and reintegrated into the surrounding community (Ekman, 2004). Additionally, these land transformation projects, if developed at a larger scale and across multiple sites, could contribute to restore natural processes and functions, create multifunctional landscapes, and promote sustainable growth (Collins, 2001). However, the complexity of these land transformation projects, evident in the number of different ways in which they have been characterized, both in the literature and by designers and other specialists who worked and/or analyzed them, contributed to decrease, somehow, their popularity, given that apart from eminent contamination and liability problems (Alberini et al., 2005; McGrath; 2000; Gibbons et al., 1998), post-industrial redevelopment processes have to also consider planning, real estate transaction and land use issues (Amekudzi, 2004; De Sousa, 2002a, and b, 2006), and community and economic development issues (Paull, 2008; De Sousa, 2006a, and b; Kaufman and Cloutier, 2006; Ozdil, 2006), among others. This means that in highly urbanized areas, community involvement may be extensive. It can be much different creating a plan where there are many concerned citizens with many expectations. Generating a plan can be a complex activity. Sometimes surface mine reclamation in a rural area, while requiring expertise, may be relatively simple, such as in Wyoming where the government and a land owner may be the primary clients to reclaim land back to high plains prairie (Burley, 2008). In a highly urbanized area, there will be various government units, local residents, and citizen groups as users and clients that can complicate the development of any plan. In such a complicated situation, some designers and planners developed community participation groups to define the goals/objectives/criteria/measures of the project to work toward an overall community satisfaction with the results (Burley and Machemer, 2016). Lawrence Halprin (1916-2009) from California and Bill Johnson from Michigan are two proponents of this 
community approach. It is much different than an elite expert designer making the decisions and designing the environment, such as the way Frank Lloyd Wright (1867-1959) or Sir Geoffrey Jellicoe developed projects as the master designer (Burley and Machemer, 2016). Both approaches can generate masterful results, but at present there is strong interest in understanding public perceptions and values to assist in community participation planning and design.

In the creation of an intervention (a design such as a reclamation plan), it has been demonstrated that the perceptions of experts and citizens do not always co-vary (Burley and Machemer, 2016). They reported that when examining visual quality, investigators kept examining aesthetic principles; yet Burley and Yilmaz (2014) and Burley (1997) revealed that citizens assess visual quality with ecological, functional, economic, cultural, and aesthetic criteria. Citizens see the world differently. To reinforce this notion, in a recent study Wen and Burley (2020a) reported upon the differences between experts and citizens in the organization of spatial properties for the management of special minority population landscapes in south-central China. The idea is not necessarily new, as Charles Jencks (1939-2009) (1997) proposed in 1977 that in architecture, structures must be divalent, meaning having both an appreciation by architects but also meaning, understanding, and comprehension by the public. He suggested that professional architects and citizens did not interpret architecture in a similar manner. The study team wondered if this was also true in post-industrial reclamation, where experts and citizens had vastly different perceptions and organization of these perceptions. This study examines the ordination of organization of perceptions by Portuguese residents concerning post-industrial reclamation to determine if they align with the descriptions, classification, and dimensions stated and declared by post-industrial professionals.

\section{Hypothesis, Methodology, and Study Areas}

This research started with the assumption that there is a relatively weak understanding of the general public's perception and expectations concerning post-industrial reclamation. The study team was interested in revealing and documenting the structure and composition of these perceptions and expectations.

Considering both the practical and theoretical state-of-the-art, it was argued that in order to achieve a successful outcome, post-industrial land transformation projects should include two different but complementary levels. The first is the preservation of a harmonious relationship among the project and its surroundings with special attention to cultural, environmental, and aesthetic assets. The second is connected with social and economic interests of the community as it relates to the perceived benefits of any project. Besides these levels, and in order to respond to 
the increasing needs of the contemporary society, the proposed interventions should increase multi-functionality, considering industrial heritage and public participation from its outset, while fostering sustainability. In this sense, the fact that "most landscape designers are inspired by and primarily focused on aesthetics; leaving society's other major objectives to secondary status" (Forman, 2002, p: 85) and that planning activities are increasingly becoming less the result of design and more the expression of economic and socio-cultural forces are considered important setbacks in achieving sustainable development.

In this regard the hypothesis which will be tested is that:

- Experts have suggested that there are three planning and design dimensions (i.e., economic, environmental, and aesthetic/socio-cultural) that need to be considered at the same level in post-industrial land transformation projects—but little empirical evidence suggests this is true, other than their proclamations. It is hypothesized that perception of citizens may ordinate the expectations and criteria for post-industrial reclamation with a different set of dimensions.

The planning and design dimensions considered in the presented hypothesis, are somehow an extension and/or adaptation of the three renowned sustainability pillars, based on the current practical and theoretical state-of-the-art. The connection between environment and aesthetics is motivated by the fact that environmental beauty has been increasingly considered a significant motive to environmental protection (Hettinger, 2007). In this sense the connection amongst these two components in a single dimension regarding post-industrial land transformation projects represents to some extent the fact that these projects should involve the integration of potential environmental functions with the improvement of its appearance and aesthetics. Socio-cultural aspects were also grouped in a single dimension not only because peoples' concern for landscape's cultural and historical components is evident (Ribeiro, 1998) but also because the people relationship is in-dissociable (Antrop, 2005).

In this scenario, the point of departure for this working hypothesis is based in several argued assumptions encompassing different aspects, some of which are deeply tested and discussed in published research others intended to be tested with a research experiment such as the present study:

- The instruments and methods used in this study (e.g., literature review and case study research) are able to identify the design principles and strategies used on the analyzed case studies (Francis, 1999). 
- Concepts such as project quality, functionality, and sustainability are normative concepts, once, even if defined in several research studies (Fuentes, 1993; Parfect and Power, 1997; Bell and Morse, 1999, 2003; Vale and Campanella, 2005; Gibson, 2007; Wu, 2007), they are not based on a set of fixed objective criteria inherent to the design and to the redevelopment process. Still it is considered that they reflect attitudes and perceptions of the society, constituting the intersection between current state of art, designer's beliefs, and the rest of the society.

- Community perception and aesthetic preferences, together with a "simplified" vision of heritage may play an important role not only in determining what is worth conserving (Edwards and Llurdes, 1996) but also in increasing the historic character, ambience, and sense and place of postindustrial landscapes (Tiesdell et al., 1996).

- The introduction of public participation is in general consequential to better decision making (Buchecker et al., 2003); however, it is not considered a "sine qua non" equation to develop better post-industrial land transformation projects.

- Although the present research constitutes a specific perspective toward the definition of a methodological approach to post-industrial land transformations projects, it is thoroughly acknowledged that it constitutes just one possibility among several others and that the definition of such framework would be augmented by a multidisciplinary approach composed by several specialists with different scientific backgrounds (Pohl, 2005; Ramadier, 2004).

- Regarding data collection and analysis it is considered that: the researcher is objective and unbiased; the data collected from the archives of the C.M.Lagoa and other Governmental and State Agencies is accurate and complete; the respondents surveyed share their objective views and honestly answer the questions posed to them regarding the study; and the primary scope of this study is limited to a specific area on the left bank of the Arade River, Algarve.

Considering the scope of the presented hypothesis and research objectives, the formulation of a few research questions, might be very helpful, not only in order to focus the investigation but also to identify key research issues. In this sense, there was an attempt to formulate two sets of questions, responding to the existing complementarity between practice and theory within the dissertation research field.

On the one hand, the ones which considered theoretical and practical evidence, regarding the test of the formulated hypothesis:

- Do industrial heritage, multi-functionality, and public participation contribute to the redevelopment of post-industrial landscapes? 
- Is public participation relevant on the design of redevelopment plans to post-industrial landscapes?

- In what form can the proposed method increase the quality of post-industrial redevelopment projects?

- What are the conceivable changes to land use patterns, given the objective of creating a multifunctional landscape and the conditions imposed by other goals such as heritage protection and environmental sustainability?

- What design and programmatic elements constitute a culturally appropriate choice in the creation of multifunctional landscapes? and

- Are democratic design techniques effective in mediating design conversations and conflicts between private and public sectors toward the creation of multifunctional redeveloped landscapes?

On the other hand, the ones regarding the analysis of the practical study area and the way it might influence and improve the quality of the final project:

- What is important in this landscape?

- What should be emphasized?

- Do these spaces fulfill the needs and desires of all the potential users of this area? and

- Which types of spaces should be created in order to respond both to socio-cultural, economic, and environmental paradigms?

While all these questions and issues are interesting and important in the development of a postindustrial project, the focus of the investigation presented here is to ascertain the ordination/dimensions of a group of respondents addressing post-industrial reclamation for a specific project and to assess how they might differ from the experts' three pillars (dimensions) of post-industrial reclamation: economic, environmental, and aesthetic/socio-cultural. The study area is along the Arade River on the west bank across from the city of Portimão, Portugal (Fig. 4). The citizen respondents are from the Portimao area. Essentially, we were intending to discover how these respondents organize and group their criteria and expectations concerning a post-industrial reclamation project on the Arade River. 


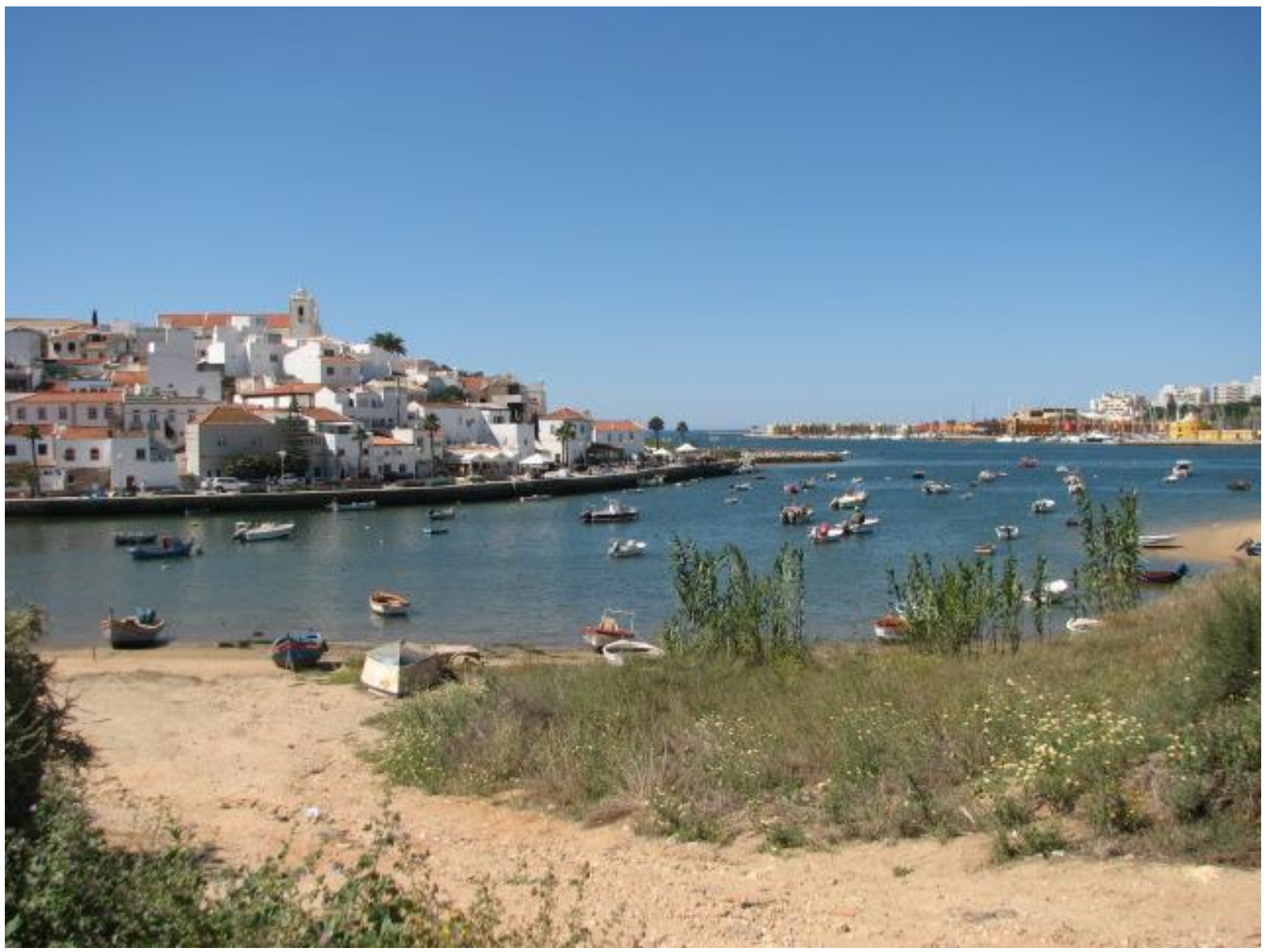

Figure 4. In the foreground is the abandoned post-industrial area, with the Arade River in the midground and the community of Portimão across the river.

To develop a list of criteria for the respondents to group and cluster, we first examined six post-industrial case studies:

- $\quad$ Duisburg Nord - Professor Peter Latz - Principal at Latz + Partner;

- $\quad$ Parque do Tejo e do Trancão - Professor João Nunes - Principal at PROAP;

- Westergasfabriek - Landscape Architect Kathryn Gustafson - Principal at Gustafson Guthrie Nichol and Gustafson Porter;

- Cleveland Valley - Tim Donovan - Director at the Ohio Canal Corridor;

- Don River Brickworks - Professor Michael Hough - Founder of the Envision - The Hough Group; and

- Millennium Park - Edward K. Uhlir - Owner at Uhlir Consulting LLC and Executive Director at Millennium Park Inc.

to understand the general understanding of the breadth of issues associated with post-industrial land transformation. Given that the contact with each selected project designer/project coordinator was considered mandatory within the present research in order to validate the identified principles, designers were contacted and requested to name the principles they used from the set of 37 
principles identified in the six analyzed case studies. Additionally they were requested to supply/mention any other principle that has been used in the development of the project and which is not listed and defined in the sent survey. After an initial contact to gauge designers' availability to answer the Design Team Member Survey, the survey instrument was sent by email to each one of the six head designers/project coordinators of the selected projects. From this interaction with experts from these six projects, we then derived a list of potential planning and design principles and criteria for further study in an approach similar to Liu and Burley (2013), asking respondents to list criteria concerning environmental quality. In addition the response of the designers/project coordinators would reveal how closely associated there values matched from what could be discerned by examining literature about the project.

In the study, planning and design experts that were not post-industrial reclamation experts were surveyed for their responses concerning the criteria. The idea was to see how wide was the variance within the profession. The survey was delivered and briefly explained to the 42 experts of the COST (European Cooperation in Science and Technology) Action, with more than 30 replies.

The public participation survey was conducted from the summer 2009 in August until late fall in November. Four hundred fifty respondents were successfully interviewed (12 questionnaires were completed in English and 438 in Portuguese). The method employed face-to-face interviews, resulting in a moderate response rate of $36.35 \%$. In order to achieve the 450 responding questionnaires, 1238 people were approached. Two of the most frequent reasons given by respondents who refused to complete the survey were: "I am too busy" and "This is just a time loss, given that the public opinion is never considered."

In the survey instrument, the public respondents were asked to select criteria from the list of 37 they believed were important to post-industrial reclamation and to place these items into the three broad categories for planning and design for post-industrial reclamation. In the results presented in this research we were seeking criteria concerning post-industrial reclamation and how it is organized. Liu and Burley (2013) discovered that their respondents' perceptions concerning "what comprises good landscape" could be divided into 31 independent dimensions, a highly complex set of expectations and perceptions, certainly not as simple as the three dimensions that some experts proposed. We wondered if post-industrial reclamation criteria would also be as dispersed or would the criteria be represented in a more simple set of criteria as identified by others? Similar multivariate Principal Component Analysis (PCA) methods can be found in works by (Wen and Burley, 2020a and b; Burley et al., 2020; Li et al., 2020; Xu et al., 2017a and b, 2016; 
Qi et al., 2012; Burley et al., 2009; 2001, Burley and Brown 1995; and Burley, Thomsen, and Kenkel, 1989). This general method was originally proposed by Kendall (1939) to study soil productivity in agriculture but became widely employed in the medical, social sciences, and geography. It was not practical until a numerical approximation method via computers was developed to produce results in dimensions greater than three. Before numerical computing, hand methods could only render results no greater than in three dimensions.

To conduct our research we asked project designers/project coordinators of noted postindustrial reclamation projects to list their criteria. Then we asked other planners and designers in Europe to select their criteria from the list, and finally we asked respondents from the public in southern Portugal to identify/select their criteria based upon the initial list. The expected result would be an ordination of dimensions related to public expectations and perceptions concerning post-industrial reclamation. Liu and Burley (2013) describe how these dimensions are formed:

We took these written answers and coded them into 65 categories. The responses were standardize to a mean of zero and a variance of one. The standardized scores were then subjected to principal component analysis, similar to the procedures described by Burley et al. (2009). The goal of the analysis is to determine if the 65 categories can be simplified into a few broad categories (eigenvalues greater than 1.0) or if there are many latent dimensions, meaning that the criteria defies reduction. If the data can be simplified, it would mean that the respondents have some unified general principles concerning the evaluation of the Dimension environment. If the list is extensive (somewhere over 10 or 12 dimensions), then one might conclude that there is no universal set of principles imbedded in the responses.

For each dimension, an eigenvector is associated with the eigenvalue. The eigenvector indicates the relative strength of each variable with the dimension. The minimum value for each coefficient of the vector is -1.0 and the maximum is 1.0. Coefficients of less than -0.4 and greater than 0.4 are considered significant (Burley et al. 2009). These significant coefficients often define the dimension, providing they are significant in one and only one dimension (Burley et al., 2009). If there are no significant variables in a dimension, coefficients closer to 0.0 can be examined. Based upon which variables are associated with each latent dimension, the dimensions are labeled/named/identified. Burley et al. provides greater detail for this methodology (Burley et al., 2009). 
With the development of the citizen dimensions, one could compare the results with the three pillars of post-industrial reclamation as proposed by experts: economic, environmental, and aesthetic/socio-cultural. If the results of the respondents are different than the experts, it does not mean the experts are wrong, but rather there are at least two different ways of view programming criteria for a project. Since post-industrial landscape interventions will most likely involve the community, it is helpful to understand the community's values. If the results reveal that indeed there are three basic dimensions (meaning three eigenvalues) and the eigenvectors align the criteria into the appropriate dimensions, then there is strong evidence that the three pillars are a strongly social construct. If there are many eigenvalues with the variables arrayed across many dimensions, then there is very little evidence that the three pillar construct is a stable socio-behavioral artifact in post-industrial planning and design.

\section{$\underline{\text { Results }}$}

According to the checklist results comparing the principles identified in each case study and the principles designers mentioned they used in their specific designs, it is noticeable in Table 1 that for all the analyzed case studies the number of principles identified throughout the analysis is smaller than the number of principles designers mentioned that were used in the design. The case study in which the difference was bigger is the Don River Brickworks Project for which according to the developed research 19 planning and design principles were identified and according to the designer, 35 principles were used (a difference of 16). On the contrary the project in which the difference was smaller was the Millennium Park, in which 24 principles were identified and the project coordinator mentioned that 33 principles were used (a difference of 9). Besides the presented data, it is important to notice that none of the designers presented any additional principle to the list of 37 . These 37 principles then formed the list of principles/design criteria in the continuation of the study. 
Table 1. Planning and Design Principles identified using case study analysis (A) vs designers opinion (D). Case study analysis results are derived from examining literature on the project and the designer opinion was through asking the designer respondent.

\begin{tabular}{|c|c|c|c|c|c|c|c|c|c|c|c|c|}
\hline \multirow{2}{*}{ Design Principles } & \multicolumn{2}{|c|}{$\begin{array}{l}\text { Duisburg } \\
\text { Nord }\end{array}$} & \multicolumn{2}{|c|}{$\begin{array}{c}\text { Tejo } \\
\text { Trancão }\end{array}$} & \multicolumn{2}{|c|}{$\begin{array}{c}\text { Westergas- } \\
\text { fabriek }\end{array}$} & \multicolumn{2}{|c|}{$\begin{array}{c}\text { Cleveland } \\
\text { Valley }\end{array}$} & \multicolumn{2}{|c|}{$\begin{array}{c}\text { Don River } \\
\text { Brickworks }\end{array}$} & \multicolumn{2}{|c|}{$\begin{array}{l}\text { Millennium } \\
\text { Park }\end{array}$} \\
\hline & $\mathbf{A}$ & D & $\mathbf{A}$ & D & $\mathbf{A}$ & D & $\mathbf{A}$ & D & $\mathbf{A}$ & D & $\mathbf{A}$ & D \\
\hline 1 Accessibility & & $X$ & $X$ & $\mathrm{X}$ & $\mathrm{X}$ & $X$ & $\mathrm{X}$ & $\mathrm{X}$ & $\mathrm{X}$ & $X$ & $\mathrm{X}$ & $\mathrm{X}$ \\
\hline 2 Adaptability and Flexibility & $X$ & $X$ & & $\mathrm{X}$ & X & $X$ & & X & & $X$ & & X \\
\hline 3 Attraction & & $X$ & $X$ & $\mathrm{X}$ & $X$ & $\mathrm{X}$ & $\mathrm{X}$ & & & & $\mathrm{X}$ & $\mathrm{X}$ \\
\hline 4 Balance and Synergy & $\mathrm{X}$ & $X$ & & $X$ & $\mathrm{X}$ & $\mathrm{X}$ & $\mathrm{X}$ & $\mathrm{X}$ & $\mathrm{X}$ & $\mathrm{X}$ & & $X$ \\
\hline 5 Character and Context & $X$ & $X$ & $\mathrm{X}$ & $\mathrm{X}$ & $\mathrm{X}$ & $X$ & $\mathrm{X}$ & $\mathrm{X}$ & $\mathrm{X}$ & $\mathrm{X}$ & $\mathrm{X}$ & $\mathrm{X}$ \\
\hline 6 Comfort & & $\mathrm{X}$ & $X$ & $\mathrm{X}$ & & $X$ & & $\mathrm{X}$ & & $X$ & $\mathrm{X}$ & $\mathrm{X}$ \\
\hline 7 Compactness and Density & & $\mathrm{X}$ & & $\mathrm{X}$ & & $\mathrm{X}$ & $\mathrm{X}$ & $\mathrm{X}$ & $\mathrm{X}$ & $\mathrm{X}$ & & $\mathrm{X}$ \\
\hline 8 Compatibility & $X$ & $X$ & & $\mathrm{X}$ & $\mathrm{X}$ & $\mathrm{X}$ & & $\mathrm{X}$ & & $X$ & & $\mathrm{X}$ \\
\hline 9 Connectivity & $X$ & $X$ & $\mathrm{X}$ & $\mathrm{X}$ & $\mathrm{X}$ & $\mathrm{X}$ & $\mathrm{X}$ & $\mathrm{X}$ & & $\mathrm{X}$ & $\mathrm{X}$ & $\mathrm{X}$ \\
\hline 10 Design for Change & & $X$ & & $\mathrm{X}$ & $\mathrm{X}$ & $\mathrm{X}$ & & & $\mathrm{X}$ & $X$ & & $\mathrm{X}$ \\
\hline 11 Distinctiveness and Identity & $X$ & $X$ & $\mathrm{X}$ & $X$ & $X$ & $X$ & $\mathrm{X}$ & $\mathrm{X}$ & $\mathrm{X}$ & $X$ & $\mathrm{X}$ & $X$ \\
\hline 12 Dynamic Context & & $X$ & X & $\mathrm{X}$ & & $\mathrm{X}$ & X & $\mathrm{X}$ & $\mathrm{X}$ & $\mathrm{X}$ & & $\mathrm{X}$ \\
\hline 13 Ease of Movement & $\mathrm{X}$ & $\mathrm{X}$ & $\mathrm{X}$ & $\mathrm{X}$ & & $\mathrm{X}$ & $\mathrm{X}$ & $\mathrm{X}$ & $\mathrm{X}$ & $X$ & $\mathrm{X}$ & $\mathrm{X}$ \\
\hline $\begin{array}{l}14 \text { Environmental Education } \\
\text { and Capital }\end{array}$ & & $X$ & $\mathrm{X}$ & $\mathrm{X}$ & & $X$ & & $\mathrm{X}$ & $\mathrm{X}$ & $X$ & $\mathrm{X}$ & $X$ \\
\hline 15 Equity & & $X$ & & $X$ & & $X$ & $\mathrm{X}$ & $\mathrm{X}$ & & $X$ & & $\mathrm{X}$ \\
\hline 16 Genius Loci & $X$ & $\mathrm{X}$ & & $\mathrm{X}$ & $\mathrm{X}$ & $X$ & $\mathrm{X}$ & $\mathrm{X}$ & $\mathrm{X}$ & $\mathrm{X}$ & & $X$ \\
\hline 17 Holistic Design & & & & $\mathrm{X}$ & $\mathrm{X}$ & $\mathrm{X}$ & $\mathrm{X}$ & $\mathrm{X}$ & & $X$ & $\mathrm{X}$ & $\mathrm{X}$ \\
\hline 18 Industrial Heritage & $X$ & $X$ & & & $X$ & $X$ & $\mathrm{X}$ & $\mathrm{X}$ & $\mathrm{X}$ & $X$ & & \\
\hline 19 Innovation and Creativity & $X$ & $X$ & $X$ & $\mathrm{X}$ & & $X$ & & & & $X$ & $\mathrm{X}$ & $X$ \\
\hline 20 Landmarks & $\mathrm{X}$ & $X$ & & $\mathrm{X}$ & $\mathrm{X}$ & $\mathrm{X}$ & $\mathrm{X}$ & $\mathrm{X}$ & $\mathrm{X}$ & $\mathrm{X}$ & $\mathrm{X}$ & $\mathrm{X}$ \\
\hline 21 Legibility & $X$ & $X$ & $\mathrm{X}$ & $\mathrm{X}$ & & $X$ & $\mathrm{X}$ & $\mathrm{X}$ & & $X$ & $\mathrm{X}$ & X \\
\hline $\begin{array}{l}22 \text { Multifunctionality and } \\
\text { Diversity }\end{array}$ & $X$ & $X$ & $X$ & $X$ & $X$ & $X$ & $\mathrm{X}$ & $X$ & & $X$ & $\mathrm{X}$ & $X$ \\
\hline 23 Partnerships & & & & & $X$ & & $\mathrm{X}$ & $X$ & $\mathrm{X}$ & $X$ & $\mathrm{X}$ & $X$ \\
\hline 24 Places for People & $X$ & $X$ & $\mathrm{X}$ & $\mathrm{X}$ & & $\mathrm{X}$ & & $\mathrm{X}$ & & $X$ & $\mathrm{X}$ & $\mathrm{X}$ \\
\hline $\begin{array}{l}25 \text { Public Participation and } \\
\text { Stakeholder Involvement }\end{array}$ & $X$ & $\mathrm{X}$ & & & $X$ & $\mathrm{X}$ & $\mathrm{X}$ & $X$ & $\mathrm{X}$ & $X$ & & $X$ \\
\hline 26 Quality Design & & $X$ & $X$ & $\mathrm{X}$ & $X$ & $X$ & & $X$ & & $X$ & $\mathrm{X}$ & \\
\hline 27 Resilience & $X$ & $X$ & X & $\mathrm{X}$ & $X$ & $\mathrm{X}$ & & $X$ & & $X$ & & $X$ \\
\hline 28 Resource Efficiency & $X$ & $\mathrm{X}$ & & $X$ & & $\mathrm{X}$ & & $\mathrm{X}$ & & $X$ & & \\
\hline 29 Reuse & $X$ & $X$ & & $X$ & $\mathrm{X}$ & $X$ & $\mathrm{X}$ & $X$ & $\mathrm{X}$ & $X$ & & \\
\hline 30 Safety and Security & & $X$ & $X$ & $\mathrm{X}$ & & $X$ & & $\mathrm{X}$ & & $X$ & $\mathrm{X}$ & X \\
\hline 31 Stigma and Value & $X$ & $X$ & & $\mathrm{X}$ & & & $\mathrm{X}$ & $X$ & & & $\mathrm{X}$ & $\mathrm{X}$ \\
\hline 32 Sustainability & & $\mathrm{X}$ & $\mathrm{X}$ & $\mathrm{X}$ & & $X$ & $\mathrm{X}$ & $\mathrm{X}$ & $\mathrm{X}$ & $X$ & $\mathrm{X}$ & $\mathrm{X}$ \\
\hline 33 Transportation network & & $\mathrm{X}$ & $X$ & $\mathrm{X}$ & $X$ & $X$ & $\mathrm{X}$ & $X$ & & $\mathrm{X}$ & $\mathrm{X}$ & $\mathrm{X}$ \\
\hline $\begin{array}{l}34 \text { Uniqueness and Cultural } \\
\text { Significance }\end{array}$ & $X$ & $X$ & & $\mathrm{X}$ & $X$ & $X$ & $X$ & $\mathrm{X}$ & $\mathrm{X}$ & $X$ & $\mathrm{X}$ & $\mathrm{X}$ \\
\hline 35 Viability & $X$ & $X$ & $X$ & $\mathrm{X}$ & & $X$ & & $\mathrm{X}$ & & $\mathrm{X}$ & $\mathrm{X}$ & $\mathrm{X}$ \\
\hline $\begin{array}{l}36 \text { Visual and Functional } \\
\text { Continuity }\end{array}$ & $\mathrm{X}$ & $\mathrm{X}$ & $\mathrm{X}$ & $\mathrm{X}$ & $X$ & $X$ & & $\mathrm{X}$ & X & $\mathrm{X}$ & $\mathrm{X}$ & $\mathrm{X}$ \\
\hline 37 Walkability & $\mathrm{X}$ & $\mathrm{X}$ & $\mathrm{X}$ & $\mathrm{X}$ & $\mathrm{X}$ & $\mathrm{X}$ & $\mathrm{X}$ & $\mathrm{X}$ & $\mathrm{X}$ & $\mathrm{X}$ & $\mathrm{X}$ & $\mathrm{X}$ \\
\hline
\end{tabular}

In the administration of the instrument to COST Action members, there were 36 responses suitable for analysis. The COST Action respondents openly placed the 37 criteria into seven different dimensions, (Table 2):

- $\quad$ sociocultural; economic; environmental and aesthetic;

- $\quad$ sociocultural + economic; sociocultural + environmental and aesthetic;

- economic + environmental and aesthetic;

- $\quad$ sociocultural + economic + environmental and aesthetic. 
Table 2. Planning and Design Response frequency of COST Action respondents to sort the 37 variables into seven different dimensions based upon the three pillars (sociocultural, economic, environmental/aesthetic).

\begin{tabular}{|c|c|c|c|c|c|c|c|}
\hline & sociocultural & economic & $\begin{array}{l}\text { environmental } \\
\text { /aesthetic }\end{array}$ & $\begin{array}{l}\text { sociocultural| } \\
\text { economic }\end{array}$ & $\begin{array}{l}\text { sociocultural | } \\
\text { environmental } \\
\text { / aesthetic }\end{array}$ & $\begin{array}{l}\text { economic } \\
\text { lenvironmental/ } \\
\text { aesthetic }\end{array}$ & $\begin{array}{l}\text { all } \\
\text { options }\end{array}$ \\
\hline 1 Accessibility & 5 & 6 & 0 & 11 & 1 & 2 & 11 \\
\hline $\begin{array}{l}2 \text { Adaptability and } \\
\text { Flexibility }\end{array}$ & 3 & 8 & 1 & 12 & 1 & 2 & 9 \\
\hline 3 Attraction & 2 & 6 & 5 & 7 & 3 & 3 & 10 \\
\hline 4 Balance and Synergy & 2 & 0 & 17 & 0 & 8 & 1 & 7 \\
\hline $\begin{array}{l}5 \text { Character and } \\
\text { Context }\end{array}$ & 7 & 0 & 5 & 2 & 16 & 1 & 5 \\
\hline 6 Comfort & 13 & 0 & 3 & 1 & 7 & 2 & 10 \\
\hline $\begin{array}{l}7 \text { Compactness and } \\
\text { Density }\end{array}$ & 0 & 7 & 6 & 0 & 4 & 9 & 10 \\
\hline 8 Compatibility & 3 & 6 & 5 & 13 & 0 & 2 & 5 \\
\hline 9 Connectivity & 3 & 4 & 7 & 7 & 3 & 4 & 8 \\
\hline 10 Design for Change & 5 & 8 & 5 & 4 & 4 & 2 & 8 \\
\hline $\begin{array}{l}11 \text { Distinctiveness and } \\
\text { Identity }\end{array}$ & 7 & 0 & 3 & 7 & 12 & 1 & 4 \\
\hline 12 Dynamic Context & 5 & 13 & 2 & 7 & 0 & 1 & 8 \\
\hline 13 Ease of Movement & 10 & 1 & 4 & 7 & 5 & 1 & 8 \\
\hline $\begin{array}{l}14 \text { Environmental } \\
\text { Education and Capital }\end{array}$ & 1 & 0 & 19 & 0 & 8 & 2 & 4 \\
\hline 15 Equity & 25 & 0 & 0 & 7 & 0 & 0 & 4 \\
\hline 16 Genius Loci & 18 & 0 & 2 & 1 & 9 & 0 & 5 \\
\hline 17 Holistic Design & 1 & 1 & 4 & 2 & 3 & 1 & 24 \\
\hline 18 Industrial Heritage & 4 & 0 & 7 & 5 & 5 & 3 & 11 \\
\hline $\begin{array}{l}19 \text { Innovation and } \\
\text { Creativity }\end{array}$ & 1 & 10 & 6 & 4 & 0 & 5 & 10 \\
\hline 20 Landmarks & 11 & 4 & 3 & 1 & 9 & 2 & 6 \\
\hline 21 Legibility & 17 & 0 & 6 & 2 & 6 & 0 & 4 \\
\hline $\begin{array}{l}22 \text { Multifunctionality } \\
\text { and Diversity }\end{array}$ & 5 & 3 & 2 & 11 & 0 & 2 & 13 \\
\hline 23 Partnerships & 3 & 17 & 0 & 8 & 0 & 1 & 6 \\
\hline 24 Places for People & 18 & 0 & 0 & 4 & 5 & 0 & 9 \\
\hline $\begin{array}{l}25 \text { Public Participation } \\
\text { and Stakeholder } \\
\text { Involvement }\end{array}$ & 12 & 2 & 1 & 9 & 0 & 0 & 12 \\
\hline 26 Quality Design & 3 & 0 & 5 & 0 & 13 & 0 & 15 \\
\hline 27 Resilience & 0 & 2 & 20 & 0 & 4 & 2 & 8 \\
\hline $\begin{array}{l}28 \text { Resource } \\
\text { Efficiency }\end{array}$ & 0 & 6 & 4 & 1 & 1 & 19 & 5 \\
\hline 29 Reuse & 2 & 8 & 9 & 3 & 0 & 7 & 7 \\
\hline 30 Safety and Security & 17 & 0 & 2 & 6 & 3 & 0 & 8 \\
\hline 31 Stigma and Value & 4 & 3 & 1 & 9 & 5 & 2 & 11 \\
\hline 32 Sustainability & 3 & 1 & 3 & 0 & 4 & 1 & 24 \\
\hline $\begin{array}{l}33 \text { Transportation } \\
\text { network }\end{array}$ & 5 & 0 & 4 & 2 & 4 & 8 & 13 \\
\hline $\begin{array}{l}34 \text { Uniqueness and } \\
\text { Cultural Significance }\end{array}$ & 13 & 0 & 3 & 2 & 12 & 2 & 4 \\
\hline 35 Viability & 0 & 6 & 1 & 5 & 2 & 8 & 14 \\
\hline $\begin{array}{l}\text { 36 Visual and } \\
\text { Functional Continuity }\end{array}$ & 2 & 0 & 11 & 1 & 14 & 2 & 6 \\
\hline 37 Walkability & 10 & 0 & 1 & 6 & 12 & 4 & 3 \\
\hline
\end{tabular}


In the Principal Component Analysis regarding the sociocultural dimension (Table 3) there were 12 significant eigenvalues, which explain $83 \%$ of the variance, while the remaining 25 dimensions contain only $17 \%$ of the variance.

Table 3. Eigenvalues.

\begin{tabular}{|c|c|c|}
\hline & Eigenvalue & Cumulative \\
\hline 1 & 5,177 & 0.157 \\
\hline 2 & 3.195 & 0.254 \\
\hline 3 & 3.031 & 0.346 \\
\hline 4 & 2.497 & 0.421 \\
\hline 5 & 2.442 & 0.495 \\
\hline 6 & 2.253 & 0.564 \\
\hline 7 & 1.933 & 0.622 \\
\hline 8 & 1.768 & 0.676 \\
\hline 9 & 1.579 & 0.724 \\
\hline 10 & 1.283 & 0.762 \\
\hline 11 & 1.188 & 0.798 \\
\hline 12 & 1.031 & 0.830 \\
\hline 13 & 0.935 & 0.858 \\
\hline 14 & 0.832 & 0.883 \\
\hline 15 & 0.746 & 0.906 \\
\hline 16 & 0.628 & 0.924 \\
\hline 17 & 0.481 & 0.939 \\
\hline 18 & 0.428 & 0.952 \\
\hline 19 & 0.331 & 0.962 \\
\hline 20 & 0.263 & 0.970 \\
\hline 21 & 0.237 & 0.078 \\
\hline 22 & 0.205 & 0.984 \\
\hline 23 & 0.160 & 0.989 \\
\hline 24 & 0.148 & 0.993 \\
\hline 25 & 0.109 & 0.996 \\
\hline 26 & 0.045 & 0.998 \\
\hline 27 & 0.037 & 0.999 \\
\hline 28 & 0.021 & 0.999 \\
\hline 29 & 0.013 & 1.000 \\
\hline 30 & 0.006 & 1.000 \\
\hline 31 & 0.000 & 1.000 \\
\hline 32 & 0.000 & 1.000 \\
\hline 33 & 0.000 & 1.000 \\
\hline 34 & 0.000 & 1.000 \\
\hline 35 & 0.000 & 1.000 \\
\hline 36 & 0.000 & 1.000 \\
\hline 37 & 0.000 & 1.000 \\
\hline
\end{tabular}

The first principal component, explaining $15.7 \%$ of the variance, is positively associated with 33 of the 37 principles, of which the principle Legibility, though not strongly associated with the dimension according to the established parameters, is the one that presents a higher eigenvector. In the second principal component, which explains $9.2 \%$ of the variance, the principle Sustainability is the one which is more strongly associated with the dimension. The third principal component was strongly associated with the principle Multi-functionality and Diversity and explained $7.6 \%$ of the variance. The fourth dimension was strongly associated with the principle Compatibility. As it happens with the first dimension, the fifth and sixth dimensions were also not strongly associated with any of the 37 principles, though the principles Distinctiveness and 
Identity and Quality Design, respectively were the ones more strongly associated with the dimension. The seventh dimension explaining 5.9\% of the variance is strongly connected with the principle Transportation Network. The eighth principal component, explaining $5.9 \%$ of the variance, is strongly associated with the principle Places for People. The ninth, tenth and eleventh dimension explaining less than $5 \%$ of the total variance each (respectively, 4.8, 3.9, and 3.6\%) are correspondingly strongly associated with the principles Attraction, Accessibility, and Dynamic Context. Finally, the twelfth dimension explaining $3.1 \%$ of the total variance, is strongly associated with principles Innovation and Creativity and Partnerships. It is clear from these results, that the Cost Action respondents were much more fragmented in opinion concerning the constituents and ordination of criteria from the three pillars. Similar fragmented results are reported for the other two pillars and can be reviewed in Loures (2010).

Table 4 presents the eigenvector coefficients for the 12 principal component explaining the association strength between identified principles and the principal component. While in the Principal Component Analysis regarding the economic dimension (Table 4) there were 9 significant eigenvalues, which explain $84.9 \%$ of the variance, the remaining 28 dimensions contain only $15.1 \%$ of the variation.

The first principal component, explaining $23.3 \%$ of the variance, though not strongly associated with any planning and design principle according to the established parameters, Legibility and Uniqueness and Cultural Significance are the principles that present higher eigenvectors. The second principal component was strongly associated both with Accessibility and Connectivity and explained $13.1 \%$ of the variance. In the third principal component, which explained $10.8 \%$ of the variance, Dynamic Context and Safety and Security are strongly associated with the dimension. The fourth dimension explained $8.9 \%$ of the variance and was strongly associated with Innovation and Creativity and Walkability. The fifth dimension explaining $7 \%$ of the variance is strongly connected with the principle Stigma and Value. Principal components sixth, seventh, eighth, and ninth are all strongly associated with two planning and design principles, respectively:

- Comfort and Compatibility;

- Adaptability and Flexibility, and Multifunctionality and Diversity;

- Comfort and Quality design; and

- Compactness and Density, and Compatibility. 
Table 4. Eigenvector coefficients for the first twelve principal components, regarding the Sociocultural dimension. Bold coefficients indicate subject categories with a strong association for a particular principal component (dimension).

\begin{tabular}{|c|c|c|c|c|c|c|c|c|c|c|c|c|}
\hline & & & & & & Eigen & vectors & & & & & \\
\hline & Prin1 & Prin2 & Prin3 & Prin4 & Prin5 & Prin6 & Prin7 & Prin8 & Prin9 & $\begin{array}{c}\text { Prin } 1 \\
0\end{array}$ & $\begin{array}{c}\text { Prin1 } 1 \\
1\end{array}$ & $\begin{array}{c}\text { Prin1 } 1 \\
2\end{array}$ \\
\hline 1 Accessibility & 0.237 & 0.200 & $\overline{0} 125$ & 0.046 & 0.104 & $\overline{-} \cdot \overline{168}$ & 0.145 & 0.108 & 0.139 & -0.411 & -0.130 & -0.046 \\
\hline 2 Adaptability and Flexibility & 0.210 & -0.174 & $\begin{array}{c}- \\
0.238\end{array}$ & 0.075 & 0.120 & $\begin{array}{c}- \\
0.043\end{array}$ & 0.126 & 0.090 & 0.046 & -0.315 & -0.153 & 0.209 \\
\hline 3 Attraction & $\begin{array}{c}- \\
0.076\end{array}$ & 0.051 & $\begin{array}{c}- \\
0.036\end{array}$ & $\begin{array}{c}- \\
0.005\end{array}$ & $\begin{array}{c}- \\
0.194\end{array}$ & 0.074 & 0.066 & -0.307 & 0.556 & 0.068 & 0.055 & 0.087 \\
\hline 4 Balance and Synergy & 0.130 & -0.257 & $\begin{array}{c}- \\
0.155\end{array}$ & 0.044 & 0.139 & 0.181 & $0 . \overline{234}$ & -0.170 & 0.039 & 0.194 & -0.048 & -0.193 \\
\hline 5 Character and Context & 0.163 & 0.123 & $\begin{array}{c}- \\
0.166\end{array}$ & $\begin{array}{c}- \\
0.114\end{array}$ & $\begin{array}{c}- \\
0.100\end{array}$ & $0 . \overline{256}$ & $\begin{array}{c}- \\
0.161\end{array}$ & -0.267 & $\begin{array}{c}- \\
0.311\end{array}$ & 0.088 & -0.118 & 0.139 \\
\hline 6 Comfort & 0.197 & 0.257 & $0 . \overline{-}$ & 0.087 & $0 . \overline{263}$ & 0.086 & 0.045 & -0.067 & 0.219 & 0.059 & 0.210 & 0.131 \\
\hline 7 Compactness and Density & 0.000 & 0.000 & 0.000 & 0.000 & 0.000 & 0.000 & 0.000 & 0.000 & 0.000 & 0.000 & 0.000 & 0.000 \\
\hline 8 Compatibility & $0 . \overline{-}$ & 0.079 & 0.005 & 0.485 & 0.216 & 0.156 & $\begin{array}{c}- \\
0.058\end{array}$ & -0.132 & $\begin{array}{c}- \\
0.130\end{array}$ & 0.225 & -0.053 & -0.129 \\
\hline 9 Connectivity & 0.257 & -0.120 & $\begin{array}{c}- \\
0.051\end{array}$ & $\begin{array}{c}- \\
0.050\end{array}$ & 0.100 & 0.207 & 0.045 & 0.253 & 0.267 & 0.228 & 0.147 & -0.070 \\
\hline 10 Design for Change & 0.106 & 0.102 & $0 . \overline{147}$ & 0.067 & $\begin{array}{c}- \\
0.154\end{array}$ & $\begin{array}{c}- \\
0.030\end{array}$ & 0.368 & 0.211 & $0 . \overline{2} 47$ & 0.291 & 0.151 & 0.061 \\
\hline 11 Distinctiveness and Identity & 0.219 & -0.014 & 0.196 & $\overline{-}-\overline{0} 26$ & 0.317 & $\begin{array}{c}- \\
0.002\end{array}$ & 0.001 & -0.017 & 0.020 & 0.144 & -0.110 & 0.071 \\
\hline 12 Dynamic Context & $\begin{array}{c}- \\
0.052\end{array}$ & -0.073 & 0.025 & 0.292 & 0.108 & $0 . \overline{2} 22$ & 0.033 & 0.225 & 0.006 & -0.133 & 0.427 & 0.363 \\
\hline 13 Ease of Movement & 0.144 & 0.259 & $\begin{array}{c}- \\
0.151\end{array}$ & 0.335 & 0.155 & $\begin{array}{c}- \\
0.166\end{array}$ & $\begin{array}{c}- \\
0.071\end{array}$ & 0.000 & $0 . \overline{0} 4$ & 0.043 & -0.228 & -0.097 \\
\hline 14 Environmental Education and Capital & 0.028 & 0.002 & 0.254 & $\begin{array}{c}- \\
0.167\end{array}$ & 0.309 & $\begin{array}{c}- \\
0.117\end{array}$ & 0.199 & -0.192 & 0.039 & 0.176 & 0.000 & -0.023 \\
\hline 15 Equity & 0.188 & 0.123 & $\begin{array}{c}- \\
0.199\end{array}$ & 0.213 & $\begin{array}{c}- \\
0.070\end{array}$ & 0.155 & $0 . \overline{254}$ & -0.169 & 0.156 & -0.113 & 0.121 & 0.019 \\
\hline 16 Genius Loci & 0.282 & -0.073 & 0.188 & 0.051 & 0.019 & $\begin{array}{c}- \\
0.181\end{array}$ & $\begin{array}{c}- \\
0.070\end{array}$ & -0.210 & $0 . \overline{165}$ & -0.195 & 0.128 & 0.119 \\
\hline 17 Holistic Design & 0.180 & -0.383 & $\begin{array}{c}- \\
0.110\end{array}$ & 0.006 & 0.100 & 0.208 & $\begin{array}{c}- \\
0.025\end{array}$ & 0.061 & 0.098 & 0.109 & -0.207 & 0.163 \\
\hline 18 Industrial Heritage & 0.254 & 0.206 & 0.097 & $\begin{array}{c}- \\
0.108\end{array}$ & 0.196 & $0 . \overline{266}$ & 0.116 & -0.006 & 0.162 & 0.065 & -0.199 & -0.016 \\
\hline 19 Innovation and Creativity & $\overline{-}-\overline{0} 8$ & 0.064 & 0.070 & 0.383 & 0.133 & $0 . \overline{-}$ & $\begin{array}{c}- \\
0.015\end{array}$ & 0.077 & 0.019 & 0.318 & 0.060 & 0.434 \\
\hline 20 Landmarks & 0.150 & 0.186 & 0.142 & $\begin{array}{c}- \\
0.254\end{array}$ & 0.086 & $\begin{array}{c}- \\
0.001\end{array}$ & 0. & 0.175 & $\begin{array}{c}- \\
0.039\end{array}$ & 0.237 & 0.246 & -0.027 \\
\hline 21 Legibility & 0.302 & -0.014 & 0.132 & 0.020 & $\begin{array}{c}- \\
0.219\end{array}$ & 0.046 & $\begin{array}{c}- \\
0.135\end{array}$ & 0.033 & $\begin{array}{c}- \\
0.260\end{array}$ & 0.032 & 0.215 & 0.052 \\
\hline 22 Multifunctionality and Diversity & 0.136 & 0.032 & 0.425 & 0.125 & 0.070 & 0.014 & 0.277 & -0.025 & $\begin{array}{c}- \\
0.012\end{array}$ & 0.090 & -0.017 & -0.115 \\
\hline 23 Partnerships & 0.097 & 0.107 & $\begin{array}{c}- \\
0.235\end{array}$ & 0.091 & 0.196 & $\begin{array}{c}- \\
0.050\end{array}$ & $\begin{array}{c}- \\
0.019\end{array}$ & 0.092 & 0.027 & -0.082 & 0.336 & -0.577 \\
\hline 24 Places for People & 0.216 & -0.131 & 0.166 & 0.087 & $\begin{array}{c}- \\
0.111\end{array}$ & 0.003 & 0.070 & $\begin{array}{c}- \\
0.460\end{array}$ & 0.061 & -0.007 & 0.031 & 0.036 \\
\hline $\begin{array}{l}25 \text { Public Participation and Stakeholder } \\
\text { Involvement }\end{array}$ & 0.209 & -0.084 & 0.056 & 0.040 & 0.269 & 0.195 & 0.030 & -0.154 & $\overline{-}-$ & -0.233 & 0.368 & 0.077 \\
\hline 26 Quality Design & 0.027 & 0.174 & 0.225 & 0.120 & $\begin{array}{c}- \\
0.078\end{array}$ & 0.348 & $\begin{array}{c}- \\
0.203\end{array}$ & 0.087 & $\begin{array}{c}- \\
0.169\end{array}$ & -0.132 & -0.092 & 0.021 \\
\hline 27 Resilience & 0.000 & 0.000 & 0.000 & 0.000 & 0.000 & 0.000 & 0.000 & 0.000 & 0.000 & 0.000 & 0.000 & 0.000 \\
\hline 28 Resource Efficiency & 0.000 & 0.000 & 0.000 & 0.000 & 0.000 & 0.000 & 0.000 & 0.000 & 0.000 & 0.000 & 0.000 & 0.000 \\
\hline 29 Reuse & 0.016 & -0.248 & 0.219 & 0.204 & $\begin{array}{c}- \\
0.279\end{array}$ & $\begin{array}{c}- \\
0.286\end{array}$ & $\begin{array}{c}- \\
0.035\end{array}$ & 0.115 & 0.035 & -0.041 & 0.077 & -0.276 \\
\hline 30 Safety and Security & 0.133 & 0.203 & 0.006 & 0.278 & $\begin{array}{c}- \\
0.321\end{array}$ & $\begin{array}{c}- \\
0.074\end{array}$ & 0.176 & -0.023 & 0.165 & 0.189 & -0.033 & -0.095 \\
\hline 31 Stigma and Value & 0.056 & 0.137 & 0.179 & 0.128 & $\begin{array}{c}- \\
0.127\end{array}$ & 0.387 & 0.210 & 0.031 & $0 . \overline{234}$ & -0.197 & -0.183 & -0.035 \\
\hline 32 Sustainability & 0.120 & $\begin{array}{c}\overline{0.434} \\
\end{array}$ & 0.116 & 0.173 & $\begin{array}{c}- \\
0.171 \\
\end{array}$ & $\begin{array}{c}- \\
0.114\end{array}$ & $\begin{array}{c}- \\
0.044\end{array}$ & 0.131 & 0.087 & 0.031 & -0.059 & -0.132 \\
\hline 33 Transportation network & 0.224 & -0.096 & $\begin{array}{c}- \\
0.182\end{array}$ & $\begin{array}{c}- \\
0.020\end{array}$ & $\begin{array}{c}- \\
0.118\end{array}$ & 0.209 & 0.437 & 0.093 & $\begin{array}{c}- \\
0.083\end{array}$ & 0.046 & -0.015 & 0.010 \\
\hline 34 Uniqueness and Cultural Significance & 0.222 & -0.075 & 0.049 & 0. & $\overline{-}$ & $\begin{array}{c}- \\
0.194\end{array}$ & $\begin{array}{c}- \\
0.294\end{array}$ & 0.240 & 0.039 & 0.086 & -0.230 & 0.056 \\
\hline 35 Viability & 0.000 & 0.000 & 0.000 & 0.000 & 0.000 & 0.000 & 0.000 & 0.000 & 0.000 & 0.000 & 0.000 & 0.000 \\
\hline 36 Visual and Functional Continuity & 0.132 & 0.191 & 0.212 & $\begin{array}{c}- \\
0.040\end{array}$ & 0.007 & 0.182 & $\begin{array}{c}- \\
0.202\end{array}$ & 0.312 & 0.231 & -0.084 & -0.149 & 0.082 \\
\hline 37 Walkability & 0.235 & -0.009 & $\begin{array}{c}- \\
0.310 \\
\end{array}$ & $\begin{array}{c}- \\
0.117 \\
\end{array}$ & $\begin{array}{c}- \\
0.093 \\
\end{array}$ & $\begin{array}{c}- \\
0.001\end{array}$ & $\begin{array}{c}- \\
0.014 \\
\end{array}$ & -0.075 & $\begin{array}{c}- \\
0.169 \\
\end{array}$ & 0.115 & -0.046 & -0.026 \\
\hline
\end{tabular}


As in the previous survey, one observation set corresponds to a completed survey by a respondent. The demographics of the respondents were comprised of men (55.33\%) and women $(44.67 \%)$. Of the respondents $41.56 \%$ were aged 30-45, which was the most frequent age group; $34.67 \%$ were aged $46-65 ; 17.78 \%$ were aged $18-29$; and only $6 \%$ were aged $>65$ years. The majority of the respondents $(51.11 \%)$ had obtained a high school level, $26.22 \%$ obtained primary school level, and $20.67 \%$ have university education. The percentage of respondents with postgraduate education was significantly low $(2.00 \%)$ of the respondents $48.44 \%$ were from Lagoa, the most populated parish of the municipality $(5,528$ people).and the rest of the respondents were more or less evenly distributed in the other parishes. While the majority of the respondents $(51.11 \%)$ considered that the environmental and aesthetic factors were the most relevant in landscape reclamation, economic aspects represented $30.00 \%$ of the responses, and sociocultural aspects $18.44 \%$.

Regarding the principal component analysis for the public respondents there were seven significant eigenvalues (principal components), explaining $68.11 \%$ of the variance (Table 5).

Table 5. Total variance explained.

\begin{tabular}{lcc} 
& Eigenvalue & Cumulative \\
\hline 1 & 2.403 & 15.020 \\
2 & 1.949 & 27.199 \\
3 & 1.745 & 38.106 \\
4 & 1.471 & 47.299 \\
5 & 1.213 & 54.883 \\
6 & 1.104 & 61.783 \\
7 & 1.012 & 68.105 \\
8 & 0.861 & 73.487 \\
9 & 0.809 & 78.543 \\
10 & 0.694 & 82.881 \\
11 & 0.652 & 86.957 \\
12 & 0.592 & 90.657 \\
13 & 0.520 & 93.909 \\
14 & 0.502 & 97.048 \\
15 & 0.472 & 100.000 \\
16 & 0.000 & 100.000 \\
\hline
\end{tabular}

The way in which these principal components are associated with the redevelopment aspects is presented in Table 6. The first principal component explaining $15.02 \%$ of the variance was strongly associated with the creation of leisure areas, tourism, mobility and accessibility, creation of green and open areas, and safety and security. The second principal component (dimension) explained $12.18 \%$ of the variance and was strongly associated with economic development, with the use of renewable energies and with the creation of residential areas. The third dimension, which explained $10.91 \%$ of the variance was strongly associated with the creation of green areas, 
industrial and built heritage, environmental preservation, and the maintenance of local character and local beauty. Principal component number 4 was strongly associated with environmental preservation, creation of residential areas, culture and local characteristics, and with the creation of habitats, and explained $7.58 \%$ of the variance. The fifth principal component explaining $6.90 \%$ of the variance, was strongly associated with environmental education and with the creation of multifunctional areas. The sixth dimension, which explained $6.32 \%$ of the variance was strongly associated with the creation of multifunctional areas, with culture and local characteristics and with the creation of habitats. Finally, the seventh principal component, which is the one that was only strongly associated with a single aspect (creation of affordable housing), explained 5.39\% of the total variance.

Table 6. Eigenvector coefficients for the first twelve principal components, regarding the Sociocultural dimension as indicated by citizen respondents. Bold coefficients indicate subject categories with a strong association for a particular principal component (dimension); while shaded ones indicate subject categories strongly associated with more than one dimension.

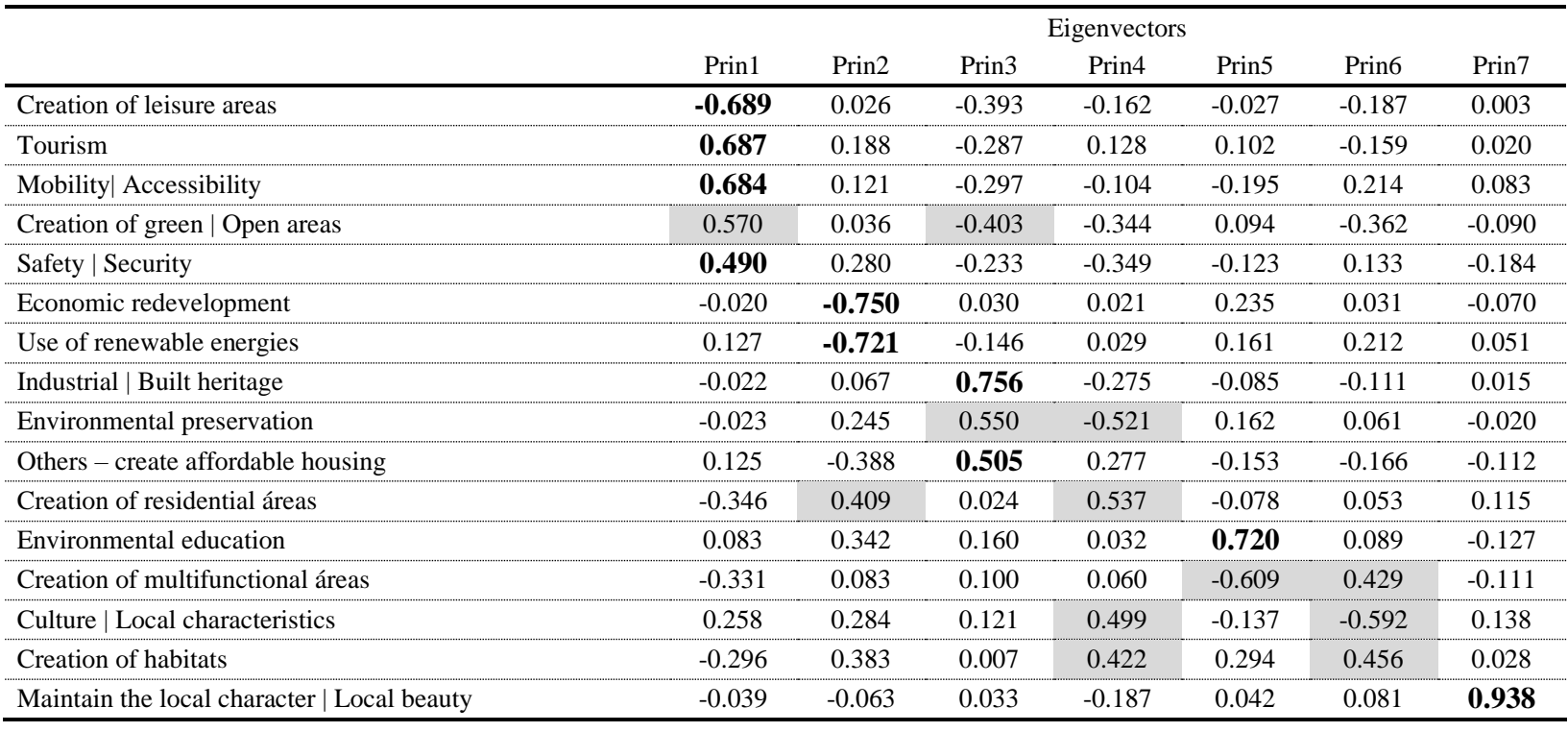

\section{Discussion and Conclusion}

Similar to Liu and Burley (2013), we do not claim that any of the dimensions are definitive. Rather the complexity of the dimensions from the principal designers of the case studies, the members of COST, and the public illustrate the complexity of the planning and design criteria. PCA suggests that many of the criteria are independent from each other and are not redundant, nor stable. Burley and Machemer (2016) suggest that satisfying one or two criteria will not satisfy other stakeholders and that numerous criteria require careful assessment before large proportions of stakeholders will be satisfied. This study reaffirms this notion. In addition the study suggests 
that the presentation of a simple list of planning and design criteria divided into three basic dimensions, as explained in previous literature, is way too simplified.

We would also like to suggest, the complexity of the criteria illustrates why many projects have difficulty with stakeholders. Planning and design projects with simplified criteria may not reflect the dispersed expectations amongst stakeholders. While a planning and design project may successfully render a few of the necessary criteria quite well, a broadly accepted project would require the successful execution of a fairly lengthy list of criteria. A client who is unwilling to accept the diversity of expectations for a project may discover resistance to the project due to unmet expectations by different sets of stakeholders.

In addition, we also believe that planners and designers such as the late Lawrence Halprin from California and William Johnson (founder of JJR in Ann Arbor, Michigan) have had success because they employed public participation activities to address planning and design solutions directly from stakeholders. This approach allowed direct in put from stakeholders. Designers (both public practice and private practice) who hold their limited number of criteria closely, may meet limited success because they do not meet the expectations of the stakeholders. Failure to be broad and encompassing may lead to delays and limited development.

We would also like to suggest the limitations of case study analysis. It was clear that the responses from experts associated with post-industrial projects were different than what could be gleaned in case study publications. It is like trying to analyze the famous Greensward Plan for New York City Central Park, 100 years after Frederick Law Olmsted and Calvert Vaux have passed away. We are suggesting that Case Study analysis might be a conservative expression concerning the intent and analysis of the planners and designers. Based upon our study alone, we believe that Case Study analysis may only be able to reveal 60 to $75 \%$ of design intent, with the rest being indiscernible.

While our study does not produce the definitive list, nor firm discrete dimensions, we believe this study illustrates that the criteria to produce successful post-industrial planning and design projects is more complicated than three or four general goals/principles/dimensions. There are numerous opportunities to explore the nature of social science expectations in planning and design in greater detail across numerous landscape settings.

It is interesting to note that the 37 criteria developed and listed in the study were not challenged, nor was additional criteria was suggested to be added. In other words, the list of criteria seems stable, but how people organize and cluster the list is not stable. In other words, a successful post- 
industrial reclamation plan might include the successful accommodation of most of the 37 variables in the plan and design, but each person and each professional might view the importance and orchestration of the variables quite differently. We suggest that this may be why urban related projects can be difficult if the planning and design team does not accommodate the many needs and expectations of the public. A brilliant engineering, technical, economic, or aesthetic solution that ignores the other criteria may lead to failure. The skill of the planner and designer is not in the ability to make a brilliant plan, despite public desire, but instead the brilliance of a plan and design may come from being able to accommodate the many diverse needs, wishes, and expectations of the public to generate a brilliant solution.

We also give a word of caution. As practitioners, we have experienced many public participation activities where the group meetings attempt to elicit votes by participants for the top three criteria or concerns. We have often witnessed extreme displeasure of some participants when the voting drowns minority concerns and passions, as planners and designers wish to simplify programming criteria for projects. Our research suggests that there is no magic subset that will win the majority of the participants; instead, it is hard work to accommodate a long list of planning and design expectations.

\section{$\underline{\text { Literature Cited }}$}

Adams, D. and C. Watkins. 2002. Greenfields, Brownfields and Housing Development. Blackwell Science Ltd, Oxford. https://doi.org/10.1002/9780470757222

Alberini, A., A. Longo, S. Tonin, F. Trombetta, and M. Turvani. 2005. The role of liability, regulation and economic incentives in brownfield remediation and redevelopment: evidence from surveys of developers. Regional Science and Urban Economics, 35(4): 327-351. https://doi.org/10.1016/j.regsciurbeco.2004.05.004

Alterman, R. 1997. The challenge of farmland preservation: lessons from a six nation comparison.

Journal of the American Planning Association, 63 (2): 220-243. https://doi.org/10.1080/01944369708975916

Amekudzi, A. 2004. Integrating brownfields redevelopment with transportation planning. Journal of Urban Planning and Development, 130(4): 204-212. https://doi.org/10.1061/(ASCE)0733-9488(2004)130:4(204)

Antrop, M. 2000. Changing patterns in the urbanized countryside of Western Europe. Landscape Ecology, 15: 257-270. https://doi.org/10.1023/A:1008151109252

Antrop, M. 2005. Why landscapes of the past are important for the future. Landscape and Urban Planning, 70: 21-34. https://doi.org/10.1016/j.landurbplan.2003.10.002 
Bell, S. and S. Morse. 2003. Measuring Sustainability: Learning by Doing. Earthscan, London. Bengston, D., J. Fletcher, and K. Nelson. 2004. Public policies for managing urban growth and protecting open space: policy instruments and lessons learned in the United States. Landscape and Urban Planning, 69(2-3): 271-286. https://doi.org/10.1016/j.landurbplan.2003.08.007

Brebbia, A., D. Almorza, and H. Klapperich. 2002. Brownfield Sites: Assessment, Rehabilitation and Development. WIT Press, Southampton.

Brueckner, J. 2000. Urban sprawl: diagnosis and remedies. International Regional Science Review, 23(2): 160-171. https://doi.org/10.1177/016001700761012710

Buchecker, M., M. Hunziker, and F. Kienast. 2003. Participatory landscape development: overcoming social barriers to public involvement. Landscape and Urban Planning, 64: 29-46. https://doi.org/10.1016/S0169-2046(02)00199-8

Burley, J.B. 1997. Visual and ecological environmental quality model for transportation planning and design. Transportation Research Record, 1549:54-60. https://doi.org/10.1177/0361198196154900107

Burley, J.B. 1989. Prospect: new perspectives on reclamation. Landscape Architecture, 79(6):120. Burley, J.B. 2001. Environmental Design for Reclaiming Surface Mines. Edwin Mellen Press.

Burley, J.B. 2008. Eastern Wyoming coal mines. Reclamation and Restoration Professional Practice Network Winter 2008 Newsletter. American Society of Landscape Architects, Washington DC.

Burley, J.B. and T.J Brown. 1995. Constructing interpretable environments from multidimensional data: GIS suitability overlays and principal component analysis. Journal of Environmental Planning and Management 38(4):537-550. https://doi.org/10.1080/09640569512805

Burley, J,B., J.M.Fernandes, and H. Cabeleira. 2006. Evolution of a hemerobiotic environment in Algarve, Portugal: European Union influences. In: Mooney, P.F. (Ed.), Shifting Ground: Landscape Architecture in the Age of the New Normal/L'architecture de paysage à l'ère de la Nouvelle Normale, CSLA/CELA 2006 Conference, June 14 - 17, 2006, Vancouver, B.C., Canada :32-37.

Burley, J.B., G.W. Fowler, K. Polakowski, and T.J. Brown, 2001. Soil based vegetation productivity model for the North Dakota coal mining region. International Journal of Surface Mining, Reclamation, and 15(4):213-234. https://doi.org/10.1076/ijsm.15.4.213.7415 
Burley, J.B., L. Loures, and M. Feng. 2012. James W. Hawks, Jr., ASLA: polychrome land development in the Upper Midwest. International Journal of Energy and Environment, 6(4): 415- 423.

Burley, J.B. and T. Machemer. 2016. From Eye to Heart: Exterior Spaces Explored and Explained. Cognella Academic Publishing, Sand Diego, California, first edition.

Burley, J.B., V.B.P. Singhal, C.J. Burley, D. Fasser, C. Churchward, D. Hellekson, and I. Raharizafy. 2009. Citation analysis of transportation research literature: a multi-dimensional map of the roadside universe. Landscape Research 34(4):481-495. https://doi.org/10.1080/01426390903009297

Burley, J.B., C. Thomsen, and N. Kenkel. 1989. Development of an agricultural productivity model to reclaim surface mines in Clay County, Minnesota. Environmental Management, 13(5):631-638. https://doi.org/10.1007/BF01874969

Burley, J.B., Z. Wu, S. He, and X. Li. 2020. Soil-based vegetation productivity models for disturbed lands along the northern and central, western Great Plains, USA. Journal of Advanced Agricultural Technologies, 7 (1): 1-7 https://doi.org/10.18178/joaat.7.1.1-7

Burley, J.B. and R. Yilmaz, 2014. Visual quality preference: the Smyser index variables. International Journal of Energy and Environment, 8:147-153.

Collins, T. 2001. Art and Ecological Restoration in Cities. In: Hall, T. and M. Miles, (Eds.), Urban Futures. Routledge, London.

Corner, J. 2006. Terra Fluxos. In: Waldheim, C. (Ed.), The Landscape Urbanism Reader. Princeton Architectural Press, New York.

Czerniak, J. 2006. Looking Back at Landscape Urbanism: Speculations on Site. In: Waldheim, C. (Ed.), The Landscape Urbanism Reader. Princeton Architectural Press, New York. pp.105123.

De Sousa, C. 2002a. Brownfield redevelopment in Toronto: an examination of past trends and future prospects. Land Use Policy, 19: 297-309. https://doi.org/10.1016/S0264-8377(02)000248

De Sousa, C. 2002b. Measuring the public costs and benefits of brownfield versus greenfield development in the greater Toronto area. Environment and Planning B, 29(2): 251-280. https://doi.org/10.1068/b1283

De Sousa, C. 2003. Turning brownfields into green space in the City of Toronto. Landscape and Urban Planning, 62: 181-198. https://doi.org/10.1016/S0169-2046(02)00149-4

De Sousa, C. 2006a. Issues Briefing: Brownfields, Greenfields, Redevelopment and Protection Linkages. Coastal Connections 2006 Land Use Roundtable. Linking Redevelopment and 
Green Space Protection in Northwest Indiana. University of Wisconsin, Milwaukee, June 28, 2006.

De Sousa, C. 2006b. Unearthing the benefits of brownfield to greenspace projects: an examination of project use and quality of life impacts. Local Environment, 11(5): 577-600. https://doi.org/10.1080/13549830600853510

Deshpande, A. 2003. Design Process to Integrate Natural and Human Systems. Master Thesis. Institute and State University, Blacksburg, Virginia.

Editorial Blau, Lta. 1998. Lisboa Expo '98: Exposição Mundial de Lisboa: Arquitectura. Editorial Blau, Lta, Lisboa, Portugal, (Portguese and Spannish lanugages).

Edwards, J. and J. Llurdes. 1996. Mines and quarries - industrial heritage tourism. Annals of Tourism Research, 23(2): 341-363. https://doi.org/10.1016/0160-7383(95)00067-4

Ekman, E. 2004. Strategies for Reclaiming Urban Post-industrial Landscapes. Master Thesis. Massachusetts Institute of Technology.

Forman, R. 2002. The missing catalyst: design and planning with ecology roots. In: Johnson, B. and K. Hill. (Eds.), Ecology and Design: Frameworks for Learning. Island Press, Washington DC. pp. 85-109.

Francis, M. 2001. A case study method for landscape architecture. Landscape Journal, 19(2): 1529. https://doi.org/10.3368/li.20.1.15

Fuentes, R. 1993. Scientific research and sustainable development. Ecological Applications, 3(4): 576-577.

Gibbons, J., N. Attoh Okine, and S. Laha. 1998. Brownfields redevelopment issues revisited. International Journal of Environment and Pollution, 10(1): 151-162. https://doi.org/10.1504/IJEP.1998.002235

Gibson, R. 2007. Sustainability Assessment: Criteria and Processes. Earthscan, London and Sterling.

Gilhaus, U., C. Oberfassel, T. Parent, D. Stemmricj, and J. Stemplewski. 2001. Emscher Revier: Industrielandscape im Prozess: Fotografien von Joachim Schumacher. LWLIndustriemuseum Zeche Zollern, Germany, (German language).

Hermann, W. and G. Hermann (Eds.). 2008. Die Alten Zechen an der Ruhr. Die Blauen Bücher, Postfach, Germany, (German lanugauge).

Hettinger, N. 007. Objectivity in environmental aesthetics and protection of the environment. In: Carlson, A. and S. Lintott. (Eds.), 2008. Nature and Aesthetics, and Environmentalism: From Beauty to Duty. Columbia University Press, New York.

Hollis, L. and W. Fulton. 2002. Open space protection: conservation meets growth management. 
Journal American Society of Mining and Reclamation, 2020 Vol.9, No 3

$\begin{array}{llll}\text { Retrieved April 26, 2009, from } & \text { 26 }\end{array}$

http://www.brook.edu/dybdocroot/es/urban/publications/hollisfulton openspace.htm

Jellicoe, G. 1996. The Collected Works of Geophrey Jellicoe: Studies of a Landscape Designer

Over 80 Years: Volume III Studies in Landscape Design. Garden Art Press,: Woodbridge, Suffolk, UK.

Jencks, C. 1997. The Language of Post-Modern Architecture. New York: Rizzoli.

Jinyan, Z., D. Xiangzheng, and Y. Tianxiang. 2003. Landscape change detection in Yulin

Prefecture. Journal of Geographical Sciences, 14(1): 47-55. https://doi.org/10.1007/BF02873090

Johnson, M. 2001. Environmental impacts of urban sprawl: a survey of the literature and proposed research agenda. Environment and Planning A 33(4): 717-735. https://doi.org/10.1068/a3327

Kaufman, D. and N. Cloutier. 2006. The impact of small brownfields and greenspaces on residential property values. Journal of Real Estate Finance and Economics, 33: 19-30. https://doi.org/10.1007/s11146-006-8272-7

Kendall, M.G. 1939. The geographical distribution of crop productivity in England. Journal of the Royal Statistical Society, 102, 21-48, https://doi.org/10.2307/2980138.

Li, N., L. Wang, X. Jin, Z. Yue, T. Machemer, J. Zhou, and J.B. Burley. 2020. An ordination of selected artists, painters, and designers: line, composition, color. Journal of Architecture and Construction, $3(1): 37-51$.

Liu, C.Q. and J.B. Burley. 2013. Landscape evaluation criteria: dispersed expectations. Modern Landscape Architecture. Proceedings of the 6th WSEAS International Conference on Landscape Architecture (LA-13), Nanjing China, November 17-19:19-23.

Loures, Luis. 2010. Planning and Design in Postindustrial Land Transformation: East Bank Arade Rive, Lagoa Case Study. Doctor of Ciencias e Technologias do Ambiente, especialidade de Planeamento Urbano, Universidade do Algarve, Faro, Portugal.

Loures, L. and T. Panagopoulos. 2006. Rehabilitation of degraded mountainous villages in Algarve, Portugal. In: Lafortezza R. and G. Sanesi (Eds.), Patterns and processes in forest landscapes: Consequences of human management. AISF Press, Florence.

Lyle, J. 1985. Design for Human Ecosystems: Landscape, Landuse and Natural Resources. Van Nostrand Reinhold, New York.

McGrath, T. 2000. Urban industrial land redevelopment and contamination risk. Journal of Urban Economics, 47(3): 414-442. https://doi.org/10.1006/juec.1999.2147

Musacchio, L., E. Ozdenerol, M. Bryant, and T. Evans. 2005. Changing landscapes, changing disciplines: seeking to understand interdisciplinarity in landscape ecological change research. 
Journal American Society of Mining and Reclamation, 2020 Vol.9, No 3

$\begin{array}{llll}\text { Landscape } \quad \text { and } & \text { 326-338. }\end{array}$ https://doi.org/10.1016/j.landurbplan.2004.08.003

Qi, J., S. Wang, J.B. Burley, and T. Machemer. (translated by Sihui Wang). 2012. Defining ecological regions in Michigan based on native tree distributions. Landscape Architecture, 2012(6):138-145.

Ozdil, T. 2006. Assessing the Economic Revitalization Impact of Urban Design Improvements: the Texas Main Street Program. Doctoral Dissertation. Texas A\&M University. Texas.

Panagopoulos, T. and L. Loures. 2007. Reclamation of derelict industrial land in Portugal: greening is not enough. Book of Abstracts of the 10th European Forum on Urban Forestry, May 16-19, 2007, Gelsenkirchen, Germany. pp. 71-72.

Panagopoulos, T. 009. Linking forestry, sustainability and aesthetics. Ecological Economics, 68: 2485-2489. https://doi.org/10.1016/j.ecolecon.2009.05.006

Parfect, M. and G. Power. 1997. Planning for Urban Quality: Urban Design in Towns and Cities. Routledge, London.

Paull, E. 2008. The Environmental and Economic Impacts of Brownfields Redevelopment. Northeast-Midwest Institute: Washington, D.C.. Retrieved March 15, 2009, from http://www.nemw.org/images/stories/documents/EnvironEconImpactsBFRedev .pdf

Peters, R. (Ed.). 1999. 100 Jahre Wasserwirtschaft im Revier: Die Emschergenossenschaft 18991999. Verlag Peter Pomp. Bottrop, Essen, Gernamy, (German Language).

Pinto-Correia, T., A. D’Abreu, and R. Oliveira. 2001. Identificação de Unidades de Paisagem: Metodologia Aplicada a Portugal. In: Finisterra, XXXVI, 72: 195-206. Retrieved August 12, 2009, from http://www.ceg.ul.pt/finisterra/numeros/2001-72/72_17.pdf

Pirelli, L. 1987. Progetto Bicocca. Edizioni Electa SpA, Milano.

Pohl, C. 2005. Transdisciplinary collaboration in environmental research. Futures, 37: 1159-1178. https://doi.org/10.1016/j.futures.2005.02.009

Portney, K. 2003. Taking Sustainable Cities Seriously: Economic Development, the Environment, and Quality of Life in American Cities. MIT Press, Cambridge. https://doi.org/10.7551/mitpress/6617.001.0001

Ramadier, T. 2004. Transdisciplinarity and its challenges: The case of urban studies. utures, 76: 423-439. https://doi.org/10.1016/j.futures.2003.10.009

Rea, C. 1991. Rethinking the Industrial Landscape: The Future of the Ford Rouge Complex. Master Thesis, Massachusetts Institute of Technology, Cambridge.

Reed, P. (Ed.). 2005. Groundwell: Constructing the Contemporary Landscape. The Museum of Modern Art, New York. 
Ribeiro, L. 1998. The Cultural Landscape and the Uniqueness of Place: a greenway heritage network for landscape conservation of Lisbon metropolitan area. Doctoral Dissertation, Department of Landscape Architecture and Regional Planning, University of Massachusetts, Amherst.

Rossi, A. 1982. The Architecture of the City. MIT Press, Cambridge.

Spirn, A. 1998. The Language of Landscape. Yale University Press, New Haven.

Tiesdell, S., T. Oc, and T. Health. 1996. Revitalizing Historic Urban Quarters. Architectural Press, Oxford.

Tyman, S. 2008. Gunpowder Park: A Case Study of Post-Industrial Reinhabitation. Master Thesis, University of Oregon, Eugene, OR.

Urban Land Institute. 2004. Barriers and Solutions to Land Assembly for Infill Development. The Urban Land Institute, Washington, DC.

Vale, L. and T. Campanella. 2005. The Resilient City: How Modern Cities Recover from Disaster. Oxford University Press, New York.

Waldheim, C. (Ed.). 2006. The Landscape Urbanism Reader. Princeton Architectural Press, New York.

Wen, B. and J.B. Burley. 2020a. Expert Opinion Dimensions of Rural Landscape Quality in Xiangxi, Hunan, P.R. of China: Principal Component Analysis and Factor Analysis. Sustainability, 12(4):1316. https://doi.org/10.3390/su12041316

Wen, B. and J.B. Burley. 2020b. Soil-based vegetation productivity model for Coryell County, Texas. Sustainability, 12(5240):1-14. https://doi.org/10.3390/su12135240

Willem, K. 2009. Taxing land for urban containment: reflections on a Dutch debate. Land Use Policy. 26(2): 233-241. https://doi.org/10.1016/j.landusepol.2008.01.006

$\mathrm{Wu}, \mathrm{F} .2007$. Re-orientation of the city plan: strategic planning and design competition in China. Geoforum, 38(2): 379-392. https://doi.org/10.1016/j.geoforum.2006.05.011

Xu, H., J.B.Burley, P. Crawford, Y. Wang, Z. Yue, and R. Schutzki. 2017a. An ordination of western and Chinese burial sites. WSEAS Transactions on Environment and Development, 13:452-469.

Xu, H., J.B. Burley, P. Crawford, and R. Schutzki. 2017b. Cross-cultural ordination of burial sites. International Journal of Cultural Heritage, 2:92-104.

$\mathrm{Xu}$, Y., J.B. Burley, P. Machemer, and A. Allen. 2016. A dimensional comparison between classical Chinese gardens and modern Chinese gardens. WSEAS Transactions on Environment and Development, 12(2016):200-213. 